\title{
Conditional Disruption of Calpain in the CNS Alters Dendrite Morphology, Impairs LTP, and Promotes Neuronal Survival following Injury
}

\author{
Mandana Amini, ${ }^{1}$ Chun-lei Ma, ${ }^{2}$ Rasoul Farazifard, ${ }^{1}$ Guoqi Zhu, ${ }^{3}$ Yi Zhang, ${ }^{1}$ Jacqueline Vanderluit, ${ }^{4}$ \\ Joanna Susie Zoltewicz, ${ }^{5}$ Fadi Hage, ${ }^{1}$ Joseph M. Savitt, ${ }^{6}$ Diane C. Lagace, ${ }^{1}$ Ruth S. Slack, ${ }^{1}$ Jean-Claude Beique, ${ }^{1}$ \\ Michel Baudry, ${ }^{3}$ Peter A. Greer, ${ }^{7}$ Richard Bergeron, ${ }^{1,2}$ and David S. Park ${ }^{1,8}$ \\ ${ }^{1}$ Cellular Molecular Medicine, School of Medicine, University of Ottawa, Ottawa, Ontario K1H 8M5, Canada, ${ }^{20 t t a w a ~ H o s p i t a l ~ R e s e a r c h ~ I n s t i t u t e ~ a n d ~}$ \\ Departments of Psychiatry and Cellular Molecular Medicine, University of Ottawa, Ottawa, Ontario K1H 8M5, Canada, ${ }^{3} \mathrm{Graduate}$ College of Biomedical \\ Sciences, Western University of Health Sciences, Pomona, California 91766, ${ }^{4}$ Division of BioMedical Sciences, Faculty of Medicine, Memorial University of \\ Newfoundland, St. John's, Newfoundland A1B 3V6, Canada, ${ }^{5}$ Banyan Laboratories, Banyan Biomarkers Inc., Alachua, Florida 32615, ${ }^{6}$ Department of \\ Neurology, Johns Hopkins University School of Medicine, Baltimore, Maryland 21287, 7Department of Pathology and Molecular Medicine, Queen's \\ University, Kingston, Ontario K7L 3N6, Canada, and ${ }^{8}$ Department of Cogno-Mechatronics Engineering, Pusan National University, Pusan 609-735, \\ Republic of Korea
}

Ubiquitous classical (typical) calpains, calpain-1 and calpain-2, are $\mathrm{Ca}^{+2}$-dependent cysteine proteases, which have been associated with numerous physiological and pathological cellular functions. However, a clear understanding of the role of calpains in the CNS has been hampered by the lack of appropriate deletion paradigms in the brain. In this study, we describe a unique model of conditional deletion of both calpain-1 and calpain-2 activities in mouse brain, which more definitively assesses the role of these ubiquitous proteases in brain development/function and pathology. Surprisingly, we show that these calpains are not critical for gross CNS development. However, calpain-1/calpain-2 loss leads to reduced dendritic branching complexity and spine density deficits associated with major deterioration in hippocampal long-term potentiation and spatial memory. Moreover, calpain-1/calpain-2-deficient neurons were significantly resistant to injury induced by excitotoxic stress or mitochondrial toxicity. Examination of downstream target showed that the conversion of the $\mathrm{Cdk} 5$ activator, p35, to pathogenic p 25 form, occurred only in the presence of calpain and that it played a major role in calpainmediated neuronal death. These findings unequivocally establish two central roles of calpain-1/calpain- 2 in CNS function in plasticity and neuronal death.

\section{Introduction}

Calpains are intracellular calcium-dependent cysteine proteases thought to regulate a diverse set of biological processes (Goll et al., 2003). There are at least 15 human calpain genes broadly divided into classical (typical) and nonconventional isoforms (Sorimachi et al., 2011). The best characterized calpains are the ubiquitously expressed classical calpain-1 and calpain-2 iso-

\footnotetext{
Received Sept. 5, 2012; revised Feb. 13, 2013; accepted Feb. 20, 2013

Author contributions: M.A. and D.S.P. designed research; M.A., C.I.M., R.F., G.Z., Y.Z., J.S.Z., F.H., and M.B. performed research; J.V., J.M.S., D.C.L., R.S.S., J.-C.B., P.A.G., and R.B. contributed unpublished reagents/analytic tools; M.A., C.-I.M., D.C.L., M.B., and R.B. analyzed data; M.A. and D.S.P. wrote the paper.

This work was supported by the Canadian Institutes of Health Research, Heart and Stroke Foundation of Ontario, Parkinson's Society Canada, Parkinson's Research Consortium, Neuroscience Canada/Krembil Foundation, Centre for Stroke Recovery, World Class University program through the National Research Foundation of Korea funded by the Ministry of Education, Science and Technology, South Korea Grant R31-2008-000-20004-0 to D.S.P., and NINDS Grant P01NS045260-01 to M.B.

The authors declare no competing financial interests.

Correspondence should be addressed to Dr. David S. Park, Department of Cellular and Molecular Medicine, University of Ottawa, 451 Smyth Road, 0ttawa, Ontario K1H 8M5, Canada. E-mail: dpark@uottawa.ca.

C.-I. Ma's present address: Department of Physiology, Binzhou Medical University, Yantai, Shandong 264003, China.

DOI:10.1523/JNEUROSCI.4247-12.2013

Copyright $\odot 2013$ the authors $\quad 0270-6474 / 13 / 335773-12 \$ 15.00 / 0$
}

forms. These are heterodimers consisting of a distinct catalytic large subunit encoded by capn1 or capn2 genes, respectively, and a common regulatory small subunit encoded by capns1 (previously known as capn4). Calpains are widely expressed in the brain (Goll et al., 2003). Functions potentially pertinent to CNS development/function include cell death (Gil-Parrado et al., 2002; Li et al., 2009), cell proliferation (Konig et al., 2003), cell signaling (Sato and Kawashima, 2001), synaptic restructuring (Zadran et al., 2010a), and synaptic plasticity (Lynch and Baudry, 1984; Denny et al., 1990; Vanderklish et al., 1996). A body of evidence also suggests that calpain regulates neuronal death in in vitro and in vivo rodent models of diverse neurodegenerative/injury conditions, such as Huntington's disease, Alzheimer's disease, ischemic stroke, and Parkinson's disease (PD) (Mouatt-Prigent et al., 1996; Crocker et al., 2003; Smith et al., 2006; Bevers and Neumar, 2008; Vosler et al., 2008). However, questions remain regarding the exact roles of calpain-1/calpain-2, particularly in the nervous system. Study of the classical calpain isoforms is further complicated by the possibility that the two calpain isoforms may compensate for each other. Germline disruption of capns1, which encodes the common small subunit of calpain-1 and calpain-2, 
has been previously shown to disrupt the activities of both these isoforms (Arthur et al., 2000). However, CAPNS1-deficient embryos die at midgestation (E11.5) because of defects in cardiovascular development, which precludes study of the nervous system using this particular animal model.

To overcome this problem, we generated a CNS-specific calpain-1/calpain-2-deficient mouse using a floxed capns1 allele combined with the Nestin-Cre transgenic driver. Using this paradigm, we have explored the role of calpain-1/calpain-2 in nervous system development and function. We were surprised to find that calpain-deficient animals survived to adulthood and brain development appeared grossly normal, given previous reports describing the essential roles of calpain in nervous system development, such as cell proliferation (Konig et al., 2003; Honda et al., 2004) and death (Sedarous et al., 2003; Vosler et al., 2008). However, phenotypic characterization of these mice revealed critical functions for calpain in synaptic plasticity and neuronal injury, which has important implications for therapeutic targeting of calpain in injury-induced or age-related degenerative diseases.

\section{Materials and Methods}

\section{Generation of CNS-specific CAPNS1 knock-out mice and genotyping}

All animal experimental studies were approved by the University of Ottawa Animal Care Committee and conformed to the guidelines set forth by the Canadian Council on Animal Care and Canadian Institutes of Health Research, and by the Institutional Animal Care and Use Committee from Western University of Health Sciences. Both male and female mice were used in all experiments. Conditionally targeted (floxed) capns1 and transgenic Nestin-Cre and TH-Cre mice were generated as previously described (Berube et al., 2005; Savitt et al., 2005; Tan et al., 2006). capns $f^{\text {flox/flox }}$ and Nestin-Cre mice were backcrossed for eight generations onto an $\mathrm{FVB} / \mathrm{N}$ background and then interbred to obtain hemizygous Nestin-Cre transgenic mice that were homozygous for the loxP targeted (floxed) capnsl gene (Nestin-Cre; capns $1^{\text {flox/flox }}$ ). These mice were referred to as CAPNS1-Nestin-cKO mice. Controls were the littermates carrying a single floxed allele of capns1 $\left(c a p n s 1^{+/ f l o x}\right)$. Similarly, the capns flox Iflox and $\mathrm{TH}$-Cre mice were backcrossed for 10 generations onto C57BL/6 strain and then interbred to obtain tyrosine hydroxylase (TH)specific calpain-deficient mice (CAPNS1-TH-cKO). All experiments were performed with CAPNS1-Nestin-cKO (FVB/N) mice, except the midbrain cultures, which were from CAPNS1-TH-cKO (C57BL/6J) mice. PCR was used to determine $\mathrm{Cre}$ sequences in tail biopsy DNA samples of Nestin-Cre and $\mathrm{TH}$-Cre mice, as described previously (Berube et al., 2005; Savitt et al., 2005). The capns1 floxed and wild-type alleles were detected using the primer set: forward, 5'-GTGGTAGCCGCTGAAACTCC-3'; reverse, 5'-TGTTCCCGCTCTCATCTGC-3'. The products were $550 \mathrm{bp}$ for the floxed allele and $515 \mathrm{bp}$ for the wild-type allele. Nonradioactive DIG labeling Southern blot hybridization analysis of brain DNA was used to confirm the excision of loxP-flanked (floxed) sequences, indicated by a $5.1 \mathrm{kbp}$ PstI fragment from the wild-type capns1 locus, a $3.2 \mathrm{kbp}$ PstI fragment from the pre-Cre floxed allele, and a $4.3 \mathrm{kbp}$ fragment from Cre recombinase-excised (post-Cre floxed) allele, as previously described (Tan et al., 2006).

\section{Immunoblotting and casein zymogram}

Total brain fractions of the CAPNS1-Nestin-cKO mice and control littermates were resolved by SDS-PAGE and PVDF immunoblots were prepared and probed using a rabbit polyclonal antisera raised against rat calpain-2 that recognizes both the small subunit $(28 \mathrm{kDa} / \mathrm{CAPNS} 1)$ and calpain-2 large subunit ( $80 \mathrm{kDa} / \mathrm{CAPN} 2)$, as previously described (Tan et al., 2006). Casein zymogram of brain lysates was used to detect calpain-1 and calpain-2 activities as previously described (Tan et al., 2006). $\alpha \mathrm{II}-$ Spectrin breakdown protein and active calpain-1 analysis was described previously (Martinez et al., 2010). Briefly, brain lysates from CAPNS1Nestin-cKO or control mice were made using $1 \%$ Triton X-100. A total of
$100 \mu \mathrm{g}$ of total protein was incubated with the following additives: $1 \mu \mathrm{g}$ purified calpain-2 + $10 \mathrm{mM} \mathrm{CaCl}_{2}$, or $10 \mathrm{mM} \mathrm{CaCl}_{2}$, or $10 \mathrm{~mm} \mathrm{EGTA}$, and incubated at room temperature for $30 \mathrm{~min}$ to allow digestion to occur. A total of $50 \mu \mathrm{g}$ of each reaction was resolved on a $4-20 \%$ gel Tris-glycine gel, blotted to PVDF, and immunoblotted with antibodies against calpain cleaved $\alpha$ II-spectrin or active calpain-1. For analysis of p35/p25 expression, whole-cell protein lysates were collected from cortical neurons treated with 1-methyl-4-phenylpyridinium $\left(\mathrm{MPP}^{+}\right)$or from cerebellar granule neurons (CGNs) treated with glutamate for the indicated times. The lysates were separated by $12 \%$ SDS-PAGE, and immunoblots were probed with anti-p35/25 antibody as described previously (O'Hare et al., 2005). Immunoblot analysis of hippocampal protein fractions for GluN1, GluN2A, GluN2B, PSD95, GluA1, and GluA2/3 was previously described (Imamura et al., 2008). Briefly, hippocampi from the brain of 4- to 6-week-old mice were dissected and homogenized using ice-cold tobacco etch virus protease lysis buffer. After a series of centrifugations, the membrane protein fractions were collected and protein concentrations were determined using the Bio-Rad protein assay. Primary antibodies included the following: anti-calpain-2 (1:1000) (Tan et al., 2006); anti- $\alpha$ II-spectrin ( $\alpha$ Fodrin, mouse monoclonal, Enzo; 1:3000); antiactivated calpain-1 (rabbit polyclonal generated in the laboratory of Banyan Biomarkers; 1:300; antibody was raised against the peptide LGRHENA corresponding to the new $\mathrm{N}$ terminus produced by calpain-1 autolysis); anti-NMDAR1 (GluN1) (rabbit polyclonal, Cell Signaling Technology; 1:1000); anti-NMDAR2A (GluN2A) and antiNMDAR2B (GluN2B) (rabbit polyclonal and mouse monoclonal, respectively, LifeSpan BioScience; 1:750); anti-GluR1 (GluA1) (rabbit monoclonal, Millipore Cell Signaling Technology Solutions; 1:5000); anti GluR2/3 (GluA2/3) (rabbit polyclonal, Millipore Bioscience Research Reagents; 1:1000); anti-PSD95 (rabbit polyclonal, Cell Signaling Technology;1:1000); and anti-p35 (p35 C-19, sc-820, Santa Cruz Biotechnology; 1:1000).

\section{Tissue preparation, immunohistochemistry, and} phenotypic analysis

Tissue preparation was previously described (Rashidian et al., 2005; Vanderluit et al., 2007). Briefly, coronal serial sections (14 $\mu \mathrm{m})$ were obtained from whole fixed cryoprotected brains of 4- to 6-week-old mice, and embryos at embryonic days (E) 13.5 and 17.5. Analyses of CA1 pyramidal cell density were performed using cresyl violet-stained sections from 4- to 6-week-old mice. CA1 neurons of hippocampus were counted using ImageJ Program in two representative sections per animal in a field of $70 \mathrm{~mm}^{2}$. For short-term BrdU incorporation experiments, pregnant dams at $13.5 \mathrm{~d}$ received a single intraperitoneal injection of $\mathrm{BrdU}(100 \mu \mathrm{g} / \mathrm{g}$ of body weight) and the embryos were collected $2 \mathrm{~h}$ after injection. To detect BrdU-labeled nuclei, sections were denatured in $2 \mathrm{~N}$ $\mathrm{HCl}$ at $37^{\circ} \mathrm{C}$ for $30 \mathrm{~min}$ and incubated in rat anti-BrdU (1:500; Accurate Chemicals \& Scientific), as previously done (Vanderluit et al., 2007). $\mathrm{BrdU}^{+}$neurons were counted on $70 \mathrm{~mm}^{2}$ of ventricular zone and subventricular zone field of 4 representative sections per embryos using ImageJ program. TUNEL assay was performed using the Roche Diagnostics TdT kit. Briefly embryonic brains at E17.5 were fixed, and $14 \mu \mathrm{m}$ sections were washed with $0.5 \%$ Triton X-100 in PBS incubated with TdT and $\mathrm{dUTP}$ at $37^{\circ} \mathrm{C}$, and then blocked with $10 \% \mathrm{BSA}^{\mathrm{TUNEL}}{ }^{+}$cells were detected by staining with Alexa streptavidin-594 and counted throughout whole sections of different regions of brains, 12 sections per brain.

\section{Golgi staining}

Golgi staining was completed using FD Rapid GolgiStain Kit (FD NeuroTechnologies). Briefly 4 - to 6-week-old naive mice were intracardially perfused with $0.9 \%$ cold saline. Forebrains within the region $\sim 0.50$ to $\sim-3.5 \mathrm{~mm}$ (relative to the bregma position) were separated and stained according to the manufacturer's instructions. Tissues were sectioned at $150 \mu \mathrm{m}$ and mounted on gelatin-coated slides. Morphology of apical and basal dendrites of hippocampal CA1 pyramidal neurons were blindly analyzed by Neurodigitech. Commercially stereology-based software (Microbrightfield), installed on a Dell PC workstation that controlled a Zeiss Axioplan 2 image microscope with Optronics MicroFire CCD camera $(1600 \times 1200$ digital camera, motorized $x, y$, and $z$-focus for high- 
resolution image acquisition and digital quantitation) was used. For cell selection, the sampling process for candidate pyramidal cells was conducted as follows: (1) previewing the entire anterior-to-posterior axis of CA1 region, under low and high magnification Zeiss objectives $(10 \times$ and $20 \times)$; (2) comparing and locating those cells with the least truncations of distal dendrites as possible under higher magnification Zeiss objectives ( $40 \times$ and $63 \times$ ); (3) after verifications, capturing low-magnification images for archiving purpose; and then (4) using a Zeiss $100 \times$ objective with immersion oil $(\mathrm{NA}=1.25)$ to perform $3 \mathrm{D}$ dendritic reconstruction. For spine sampling, only spines orthogonal to the dendritic shaft were readily resolved and included in this analysis, whereas spines protruding above or beneath the dendritic shaft were not sampled. Spines were counted throughout the entire dendritic trees. For Scholl analysis, a series of concentric circles ( $30 \mu \mathrm{m}$ interval) radiating from the soma was set up. All data represented the average for neurons.

\section{Electrophysiology}

Whole-cell recordings. Coronal brain slices containing the hippocampus were obtained as described previously (Imamura et al., 2008). In brief, 4to 6-week-old mice were anesthetized with isofluorane in agreement with the guidelines of the Canadian Council of Animal Care. The brain was removed and placed in an oxygenated $\left(95 \% \mathrm{O}_{2}, 5 \% \mathrm{CO}_{2}\right)$ artificial CSF (ACSF) at $4^{\circ} \mathrm{C}$, containing (in mM) $126 \mathrm{NaCl}, 2.5 \mathrm{KCl}, 1 \mathrm{MgCl}_{2}, 26$ $\mathrm{NaHCO}_{3}, 1.25 \mathrm{NaH}_{2} \mathrm{PO}_{4}, 2 \mathrm{CaCl}_{2}$, and 10 glucose. The osmolarity of the ACSF was adjusted to $300 \mathrm{mOsmol}$ and the $\mathrm{pH}$ to 7.2. A vibrating microtome (VT 1000S; Leica) was used to obtain coronal sections $(300 \mu \mathrm{m})$ containing the hippocampus. Acute brain slices were stored for at least $1 \mathrm{~h}$ in an oxygenated chamber at room temperature before recording. Voltage-clamp recordings of CA1 pyramidal cells were obtained with a Multiclamp 700A amplifier (Molecular Devices) under visual control using differential interference contrast and infrared video microscopy (Leica). EPSCs were evoked by electrical stimulation of the Schaffer collaterals with a bipolar microelectrode positioned in stratum radiatum with $100 \mu$ s current pulses $(0.1-1 \mathrm{~mA}, 0.3-0.01 \mathrm{~Hz})$, which were adjusted to evoke a current amplitude in the range of $60-120 \mathrm{pA}$ at $\mathrm{V}_{\mathrm{m}}=-65$ $\mathrm{mV}$. Patch-clamp recordings were obtained in pyramidal cells of CA1 region in hippocampus in normal ACSF. For recordings of EPSCs mediated by glutamate receptors (both AMPA receptor and NMDA receptor EPSCs), brain slices were bathed in ACSF containing picrotoxin $(50 \mu \mathrm{M})$ and strychnine $(1 \mu \mathrm{M})$. For recordings of NMDA receptor-mediated EPSCs, brain slices were bathed in low $\mathrm{Mg}^{2+}$ ACSF containing picrotoxin (50 $\mu \mathrm{M})$, strychnine $(1 \mu \mathrm{M})$, and 2,3-dihydroxy-6-nitro-7-sulfamoylbenzo[f] quinoxaline ( $5 \mu \mathrm{M})$; for recordings of miniature EPSCs (mEPSCs), brain slices were perfused in low $\mathrm{Mg}^{2+} \mathrm{ACSF}$ containing TTX $(1 \mu \mathrm{M})$, picrotoxin $(50 \mu \mathrm{M})$, strychnine $(1 \mu \mathrm{M})$, CGP52432 $(10 \mu \mathrm{M})$; for LTP, brain slices were bathed in ACSF containing picrotoxin $(50 \mu \mathrm{M})$ and strychnine $(1 \mu \mathrm{M})$. The $\mathrm{pH}$ of the perfusion solution was adjusted to 7.2 and osmolarity to 300 mOsm. Recording electrodes were filled with an intracellular solution (in $\mathrm{mm}$ ): $130 \mathrm{Cs}^{+}$-methanesulphonate, $10 \mathrm{HEPES}, 10 \mathrm{KCl}, 2 \mathrm{MgCl}_{2}, 0.2 \mathrm{EGTA}$, 2 ATP-Mg, and 0.2 GTP-Tris (hydroxymethyl) aminomethane and lidocaine $N$-ethyl bromide (QX-314, $5 \mathrm{~mm}$ ). The $\mathrm{pH}$ of the intracellular solutions was adjusted to 7.2, and the osmolarity was 280-290 mOsm. The pipettes had a resistance of 3-7 M 2 . For eliciting LTP a pairing protocol composed of three brief high-frequency trains $(50$ pulses at $100 \mathrm{~Hz})$ repeated at $4 \mathrm{~s}$ intervals given at the end of a long depolarization $(3 \mathrm{~min}$ at $0 \mathrm{mV}$ ) was used. This protocol has been successfully used before to induce an increase of synaptic responses lasting for $>40 \mathrm{~min}$ (Chen et al., 1999; Martina et al., 2004). Data were collected by Pclamp 9 software (Molecular Devices). Analyses were performed using Igor software (WaveMetrics).

Field potential recording. Three- to 4-month-old male mice were anesthetized with halothane and decapitated. Brains were quickly removed and transferred to oxygenated, ice-cold, high-magnesium cutting medium (in mм: $124 \mathrm{NaCl}, 26 \mathrm{NaHCO}_{3}, 10$ glucose, $3 \mathrm{KCl}, 1.25 \mathrm{KH}_{2} \mathrm{PO}_{4}, 5$ $\mathrm{MgSO}_{4}$, and $3.4 \mathrm{CaCl}_{2}$ ). Hippocampal transversal slices (400 $\mu \mathrm{m}$ thick) were prepared using a McIlwain-type tissue chopper and transferred to an interface recording chamber and exposed to a warm, humidified atmosphere of $95 \% \mathrm{O}_{2} / 5 \% \mathrm{CO}_{2}$ and continuously perfused with oxygenated and preheated $\left(33 \pm 0.5^{\circ} \mathrm{C}\right) \mathrm{ACSF}$ (in mM: $110 \mathrm{NaCl}, 5 \mathrm{KCl}, 2.5$ $\mathrm{CaCl}_{2}, 1.5 \mathrm{MgSO}_{4}, 1.24 \mathrm{KH}_{2} \mathrm{PO}_{4}, 10$ glucose, $27.4 \mathrm{NaHCO}_{3}$ ) at $1.4 \mathrm{ml} /$ $\min$. After $1.5 \mathrm{~h}$ incubation at $33 \pm 0.5^{\circ} \mathrm{C}$ in the recording chamber, a single glass pipette filled with $2 \mathrm{M} \mathrm{NaCl}$ was used to record field EPSPs (fEPSPs) elicited by stimulation of the Schaffer collateral pathway with twisted nichrome wires (single bare wire diameter, $50 \mu \mathrm{m}$ ) placed in CA1 stratum radiatum. Responses were recorded through a differential amplifier (DAM 50, World Precision Instruments) with a $10 \mathrm{kHz}$ high-pass and $0.1 \mathrm{~Hz}$ low-pass filter. Before each experiment, the input/output relation was examined by varying the intensity of the stimulation. Data were collected and digitized by Clampex, and the amplitude of fEPSP was analyzed.

All data are expressed as mean \pm SEM, and statistical significance of differences between means was calculated with appropriate Student's $t$ test.

\section{Behavioral analysis}

All behavioral tests were completed in the Behavior Core Facility at the University of Ottawa using standardized protocols. Animals were habituated to the testing room $\sim 1 \mathrm{~h}$ before testing. One cohort of mice (3- to 4-month-old) was used for beam break, rotarod, elevated plus maze, and open field within at least $2 \mathrm{~d}$ between tests. Because of aging deficits in vision that can occur in the FVB/N strain, a separate cohort of younger mice (4- to 6-week-old) was examined for the water maze paradigm.

Beam Break. Locomotor activity over a $24 \mathrm{~h}$ period was analyzed by using the computer-assisted beam break, MicroMax system (Accuscan) as previously reported (Smith et al., 2006).

Rotarod. The rotating rod test was performed on an accelerating rotarod (IITC Life Science; length of the test 2 min; accelerating speed 1-45 $\mathrm{rpm})$. The time until the animal falls off the rotating rod was measured in four tests performed on two consecutive days.

Elevated Plus Maze. The arms were $\sim 12 \mathrm{~cm}$ wide and $\sim 50 \mathrm{~cm}$ long and the maze was raised $\sim 1 \mathrm{~m}$ off the floor. The times spent in the open arms, closed arms, and center of the elevated plus-maze apparatus were recorded for 10 min using the Ethovision software.

Open field. Mice were placed in the corner of a wooden box measuring $45 \mathrm{~cm} \times 45 \mathrm{~cm} \times 45 \mathrm{~cm}$ and allowed to freely explore for $10 \mathrm{~min}$. The main outcome measures included the time spent in the center, distance traveled and velocity were detected by a video camera using the Ethovision software.

Morris Water Maze. The water maze pool was filled with opaque water and heated to remain at $21^{\circ} \mathrm{C}$. A white platform was submerged $1 \mathrm{~cm}$ below the water's surface in the center of the target quadrant. Mice were randomly placed on one of starting points in one of the four quadrants and given $60 \mathrm{~s}$ to find the hidden platform. Mice that did not find the platform at the end of the $60 \mathrm{~s}$ period were led to the platform and were allowed to stay on it for $20 \mathrm{~s}$. Each mouse had 4 trials per day for 11 consecutive days. An animal was scored as successfully finding the platform if it succeeded in two of four trials per day. In the visual tests, mice were placed on one of four quadrants and allowed to find the visible platform in $60 \mathrm{~s}$. The swimming path of the mice was recorded by a video camera and analyzed by the Ethovision 7 XT.

\section{Assessment of in vitro neuronal survival}

Primary cortical neuron cultures were prepared from 14 to $15 \mathrm{~d}$ embryos individually as previously described (Kim et al., 2005). Cultured neurons were treated with $\mathrm{MPP}^{+}$at a final concentration of $20 \mu \mathrm{M}$ after $2 \mathrm{DIV}$. Numbers of viable neurons were evaluated by lysis of cultures followed by counting intact nuclei as described previously (Kim et al., 2005). For midbrain cultures, mesencephalic neurons were collected from day 13 to day 14 embryos as described previously (Kim et al., 2005). $\mathrm{MPP}^{+}$treatment started on 7 DIV at $20 \mu \mathrm{m}$ final concentration for desired time periods. Cells were stained with anti-TH antibody (ImmunoStar; 1:2500) as primary antibody and Hoechst as the control. Fluorescent-stained $\mathrm{TH}^{+}$neurons were counted and evaluated for nuclear, dendrite, and axon morphology. CGNs were harvested from 7 to $8 \mathrm{~d}$ pups, and glutamate- or hypoxia-induced excitotoxicity was performed as described previously (Rashidian et al., 2005). Cell survival was evaluated as indicated previously (Kim et al., 2005). For rescuing survival phenotype, both cortical neurons and CGNs were infected with adeno-associated virus (AAV) expressing p25 or with AAV-GFP (multiplicity of infection, 
25) at the time of plating. $\mathrm{MPP}^{+}$was added to cortical neurons on 6 DIV at a final concentration of $20 \mu \mathrm{M}$. Glutamate treatments were completed on 8 DIV. Neuron viability was evaluated by counting the number of intact nuclei as described previously (Kim et al., 2005).

\section{AAV construct}

cDNA sequences of human p25 were subcloned into the BamHI-EcoRI sites of the AM/CBA-pl-WPRE-bGH plasmid, a recombinant AAV (rAAV1) vector. The virus was then generated and purified as described previously (Rashidian et al., 2005). EGFP was excised from Clontech pEGFP-N2 vector (catalog \#6081-1) using BamHI and a blunted NotI. This fragment was subsequently subcloned into the same AAV vector, AM CBA-pl-WPRE-bGH, into the BamHI and EcoRV sites to produce AAV-CBA-EGFP-WPRE-bGH.

\section{Data and statistical analysis}

Statistical analysis was performed using SPSS Statistics 18 and included use of one of the following: (1) two-tailed Student's $t$ test for comparison of two groups, (2) one-way ANOVA for comparison of four groups on one outcome measure, (3) two-way ANOVA for more than one group on more than one outcome measure, (4) repeated ANOVA (for repeated measure on same animal), and (5) $\chi^{2}$ to examine the distribution of animals achieving preset criteria. All post hoc tests were completed using Bonferroni correction. In analyses that included both male and female animals, sex differences were also tested. However, as all comparisons between sexes did not reveal any differences, only grouped data for controls and mutants are shown. Significance is indicated when $p<0.05\left(^{*}\right)$.

\section{Results}

\section{Elimination of calpain-1 and calpain- 2 activities in} mouse brain

We used a Cre/loxP-mediated recombination strategy to conditionally target the capns1 locus in the mouse brain. Exons 9, 10, and 11 of capns 1 were flanked by loxP sites as described previously (Tan et al., 2006). To obtain CNS-specific disruption of calpain1/calpain-2 activity, capns $1^{\text {flox/flox }}$ mice were crossed with NestinCre transgenic mice expressing Cre recombinase under the control of the nestin promoter, to create Nestin-Cre; capns $1^{\text {flox } / \text { flox }}$ (CAPNS1-Nestin-cKO) mice. Nestin is an intermediate filament expressed specifically in CNS precursor cells (Berube et al., 2005). Surprisingly, the CAPNS1-Nestin-cKO were viable, fertile, and born at approximate Mendelian ratios ( $n=49$ of $225 ; 21.7 \%$ ).

Southern blot analysis of genomic DNA revealed that complete excision of capns1 occurred only in the brains of mice that were transgenic for Nestin-Cre and homozygous for the loxP targeted (flox) capns1 gene. These CAPNS1-Nestin-cKO mice brains demonstrated near-complete excision of floxed capns1 alleles, as determined by the generation of a $4.3 \mathrm{kbp}$ size post-Cre allele fragment (Fig. 1a). To assess calpain expression in the brains of these mice, we first performed immunoblot analysis using an antibody raised against calpain-2, which recognizes both the $28 \mathrm{kDa}$ capns 1 and $80 \mathrm{kDa}$ capn 2 gene products. As expected, the brains of CAPNS1-Nestin-cKO mice displayed complete loss of the $28 \mathrm{kDa}$ subunit. Importantly, and as previously reported, loss of CAPNS1 also led to the loss of $80 \mathrm{kDa}$ CAPN2 protein presumably because of the destabilizing effects of CAPNS1 loss (Arthur et al., 2000; Chung et al., 2004) (Fig. 1b). The effect of capns 1 targeting in brain on calpain protease activity was assessed using two methods. First, casein zymogram analyses of brain lysates showed no detectable calpain-1 or calpain-2 activity in the brains of CAPNS1-Nestin-cKO mice (Fig. 1b), whereas robust activity for both calpain isoforms was observed in controls. Second, endogenous calpains were activated in vitro in whole brain lysates by adding $\mathrm{CaCl}_{2}$, which yielded the well-characterized calpain-specific spectrin breakdown products (Zhang et al.,
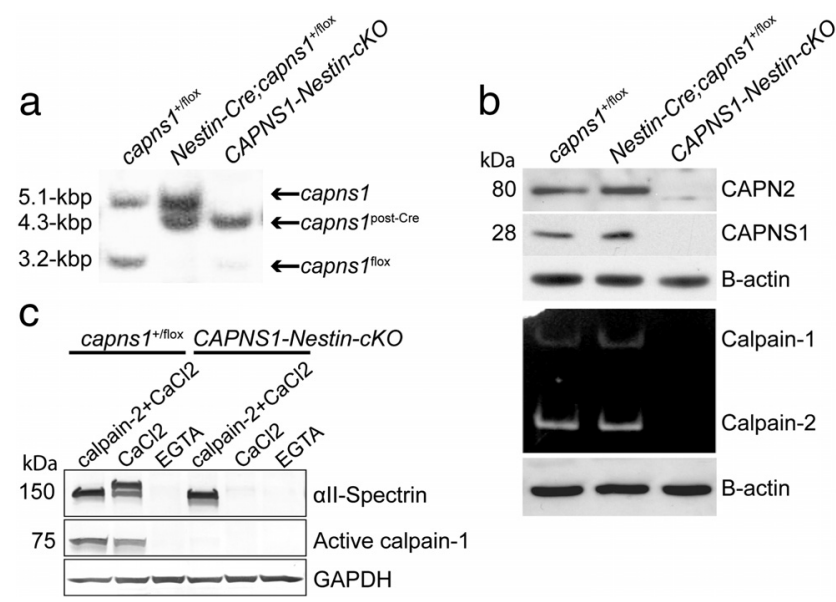

Figure 1. Disruption of calpain-1 and calpain-2 expression and activities in the CAPNS1-NestinCKOmousebrain. $\boldsymbol{a}$, Southern blot analysis of brain DNA samples from CAPNS1-Nestin-cKO (Nestin-Cre; capns $1^{\text {floxfflox}}$ ) and control littermates (Nestin-Cre; capns $1^{+ \text {fflox }}$ or capns $1^{+/ \text {ffox }}$ ). The probe distinguishes 5.1, 4.3, and 3.2 kbp Pstl fragments corresponding to untargeted (capns 7 ) or the floxed allele after (capns $7^{\text {post-Cre }}$ ) or before (capns $7^{f l o x}$ ) Cre-mediated excision, respectively. $\boldsymbol{b}$, Top, Representative immunoblot of calpain-2 (CAPN2) $(80 \mathrm{kDa}$ ) and CAPNS1 (28 kDa) proteins extracted from brains of CAPNS1-Nestin-CKO and control littermates probed with calpain-2 antibody. Bottom, Casein zymogram of the brain total fraction to analyze calpain- 1 and calpain-2 activities ( $n=5$ per genotype). $c$, Representative immunoblot of brain total protein extracts probed with indicated antibodies for $\alpha$ llspectrin and active calpain- 1 ( $n=3$ per genotype). $\mathrm{CaCl}_{2}$ triggered cleavage of spectrin to its calpainspecific 145 and $150 \mathrm{kDa}$ breakdown products in control but not CAPNS1-Nestin-CKO brain extracts, whereas addition of rat calpain-2 enzyme cleaved spectrin to $150 \mathrm{kDa}$ in brain lysates of both genotypes.

2009), SBDP145 and 150, in control but not in CAPNS1Nestin-cKO brain extracts (Martinez et al., 2010). Disruption of calpain activity was further supported using an antibody specific for the active form of calpain-1, which did not detect the active $80 \mathrm{kDa}$ catalytic subunit in CAPNS1-Nestin-cKO brain lysates (Fig. 1c). Together, these results provided compelling evidence of calpain deficiency in the brains of CAPNS1-Nestin-cKO mice.

\section{Calpain-deficient mice do not show detectable gross morphological abnormalities}

The importance of calpain in early murine development was underscored by the lethality observed in both capns1 and capn2 germline knock-out mice (Arthur et al., 2000; Dutt et al., 2006). The viability of adult CAPNS1-Nestin-cKO animals with brainspecific calpain deficiency allowed us to explore the role of calpain in CNS development. Serial coronal sections of brains from mutant and control littermates at developmental stages and adults were stained with cresyl violet. Unexpectedly, we did not detect any gross morphological or structural abnormalities in the brain regions and neurons of the mutants either at E13.5 (data not shown), E17.5, or 4- to 6-week-old adult mice (Fig. 2a,b). Quantification of hippocampal CA1 neurons in the mutants demonstrated the same number of pyramidal neurons as in controls (Fig. 2c). We also examined whether neuronal precursor proliferation was altered in mutant mice. Embryos at E13.5 were subjected to short-term BrdU labeling and BrdU-positive nuclei were evaluated in the ventricular zone and subventricular zone of the brain. No differences in the number of proliferating cells were detected between mutant and control mice (Fig. 2d). Similarly, developmental programmed cell death (i.e., apoptosis) was detected by TUNEL staining at E17.5. Equal numbers of scattered TUNEL-positive cells were observed in both genotypes (Fig. 2e). 
a

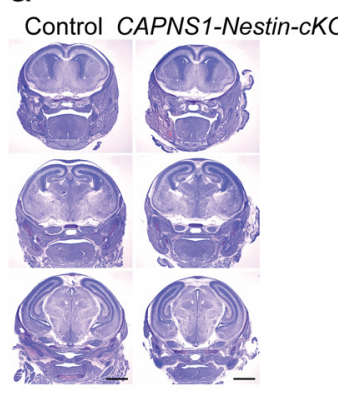

b

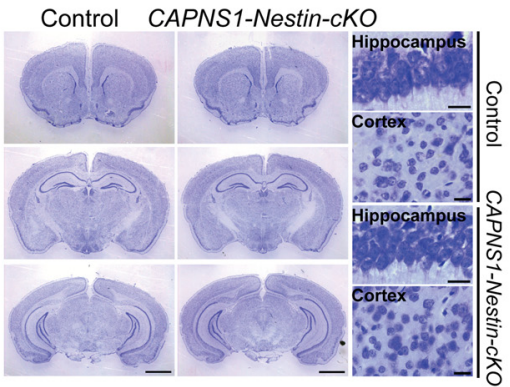

d

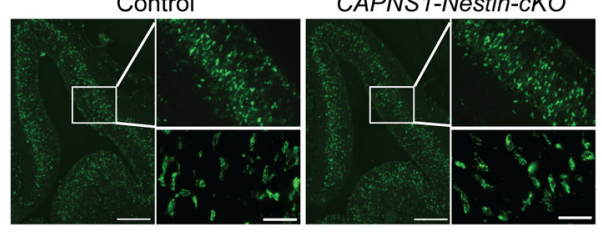

C
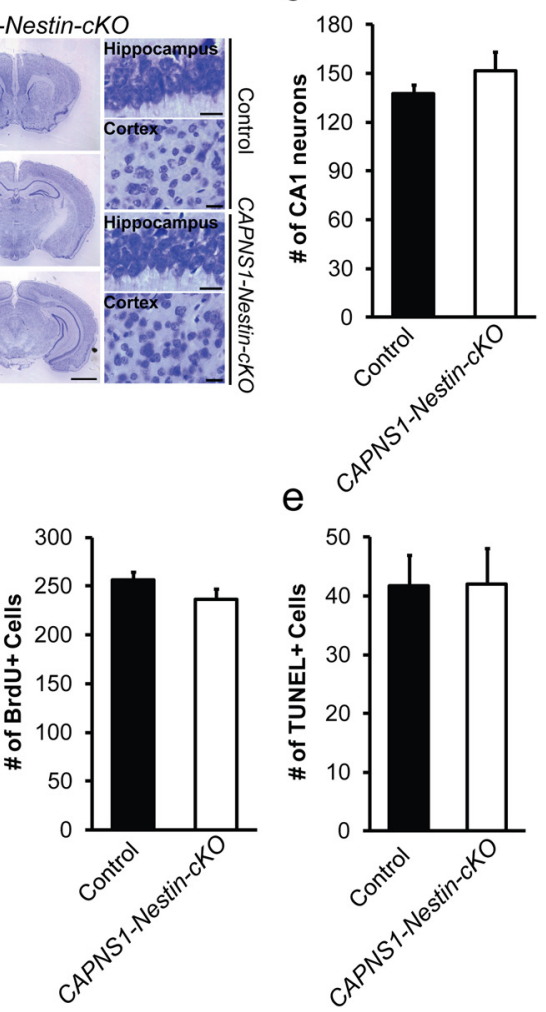

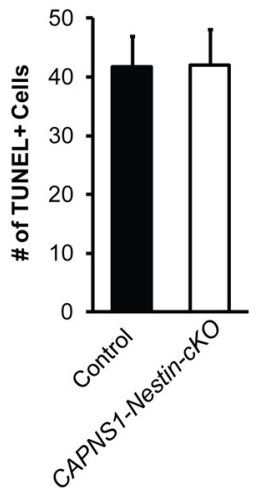

Figure 2. Histological assessment of CAPNS1-Nestin-CKO mice compared with control littermates. $\boldsymbol{a}, \boldsymbol{b}$, Representative cresyl violet staining of coronal sections through different regions of brains from (a) E17.5 and (b) 4- to 6-week-old adult CAPNS1-NestincKO mice and controls, respectively, including different regions (scale bar, $1 \mathrm{~mm}$ ) and neurons in hippocampus and cortex (scale bar, $20 \mu \mathrm{m})$. c, Number of CA1 neurons in defined fields at 4 to 6 weeks of age ( $n=3$ per genotype). $\boldsymbol{d}$, Representative photomicrographs of BrdU-stained sections of embryonic brains from CAPNS1-Nestin-cKO and control littermates. Scale bar: left, $175 \mu \mathrm{m}$; right, $20 \mu \mathrm{m}$. Number of BrdU-positive cells were counted in defined fields of sections ( $n=4$ per genotype). $\boldsymbol{e}$, Number of TUNEL-positive cells throughout whole brain sections ( $n=3$ per genotype).

These results indicate that calpain-1/calpain-2 isoforms do not play essential roles in regulating developmental cell proliferation/ apoptosis or the gross organization or structure of the developing and adult brain.

\section{Dendrite morphology alterations in calpain-deficient CA1 pyramidal neurons}

Because calpain has been suggested to modify cytoskeletal proteins (Wilson et al., 2000), we sought to investigate whether dendritic structures of CA1 hippocampal neurons were altered in CAPNS1-Nestin-cKO. We thus performed Golgi staining of dorsal hippocampus in 4- to 6-week-old controls and conditionally calpain-deleted brains. Representative photomicrographs of CA1 pyramidal neurons and segments of apical and basal dendrites in control littermates and CAPNS1-Nestin-cKO mice are shown in Figure $3 a$. We observed a significant reduction in the density of dendritic spines along the apical branches of CA1 pyramidal neurons of the mutants. This decrease in spine density was also accompanied by a significant decline in total spine counts in apical dendrites in calpain-deficient mice (Fig. 3b,c). Moreover, apical and basal dendritic complexity and spine distribution were reduced in CA1 pyramidal neurons of CAPNS1-Nestin-cKO, as revealed by Scholl analysis (Fig. $3 d, e$ ). Finally, no significant changes were observed in dendritic lengths with calpain deficiency (Fig. 3f). These results suggest a critical role of calpain in regulation/organization of dendritic trees in hippocampal CA1 neurons.

Effect of calpain deficiency on glutamatergic synaptic transmission and LTP

The overall alterations observed in dendritic complexities and spine density in CAPNS1-Nestin-cKO suggested that calpain may play a role in modulating glutamatergic synaptic transmission. To begin addressing this possibility, we measured the expression of a number of AMPA and NMDA receptor subunits in isolated membrane fractions from hippocampi of 4- to 6-week-old CAPNS1-Nestin-cKO and controls. Intriguingly, we observed robust reductions in the levels of the NMDA receptor subunits GluN1, GluN2A, and GluN2B as well as of the AMPA receptor subunits GluA1 and GluA2/3. Finally, the expression of PSD95 was also reduced in mutant mice compared with control littermates (Fig. 4a).

These results prompted us to examine in greater detail metrics of glutamatergic synaptic transmission by whole-cell recordings of CA1 pyramidal cells in acute slices from CAPNS1-Nestin-cKO mice and controls. We first determined the ratio of AMPA to NMDA receptor components of evoked EPSCs in both types of mice. When holding the cell at $+40 \mathrm{mV}$, both AMPA and NMDA receptors are activated by synaptically released glutamate, and their respective contribution to the evoked EPSCs can be approximated because AMPA receptor- and NMDA receptor-mediated synaptic responses are kinetically distinguishable. Under these conditions, the AMPA/NMDA ratio of evoked EPSCs was indistinguishable between CAPNS1-Nestin-cKO and control mice (Fig. 4b). Moreover, the decay kinetics of both isolated AMPA receptor- or NMDA receptor-mediated (in low $\mathrm{Mg}^{2+}$ ) EPSCs were likewise not altered in mutant mice (Fig. 4c), suggesting that no obvious changes in surface glutamate receptor subunit composition occurred in these mice. We next recorded spontaneous mEPSCs in CA1 pyramidal neurons and observed no significant changes in the amplitudes or the frequency of mEPSCs in calpain-deficient mice, compared with control animals (Fig. 4d). These results are in agreement with those of the AMPA/NMDA receptor ratio and suggest that deletion of calpains did not alter the expression of AMPA receptors at individual synapses, or the probability of release of glutamate. The latter possibility was further examined by paired pulse ratio analysis, a measure of presynaptic neurotransmitter release probability. As expected for CA1 synapses, paired pulse facilitation was observed at intervals of 50, 100, and $200 \mathrm{~ms}$, and this ratio was not altered in CAPNS1Nestin-cKO mice (Fig. 4e). Together, these observations argue that, although calpain deficiency was accompanied with reduced levels of a variety of synaptic proteins, this was not associated with measurable deficits in basal excitatory glutamatergic synaptic neurotransmission.

We further analyzed properties of synaptic transmission in the CA1 field of hippocampal slices from control and CAPNS1Nestin-cKO mice by field recording. No alteration was observed in paired-pulse facilitation in the absence of calpain (data not 


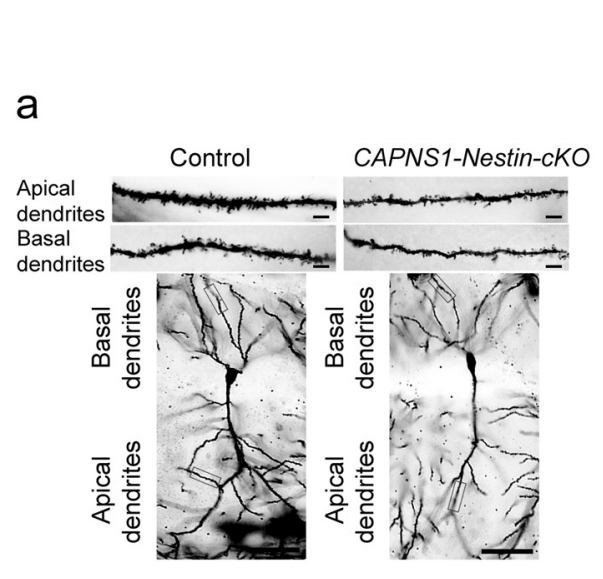

$\mathrm{b}$
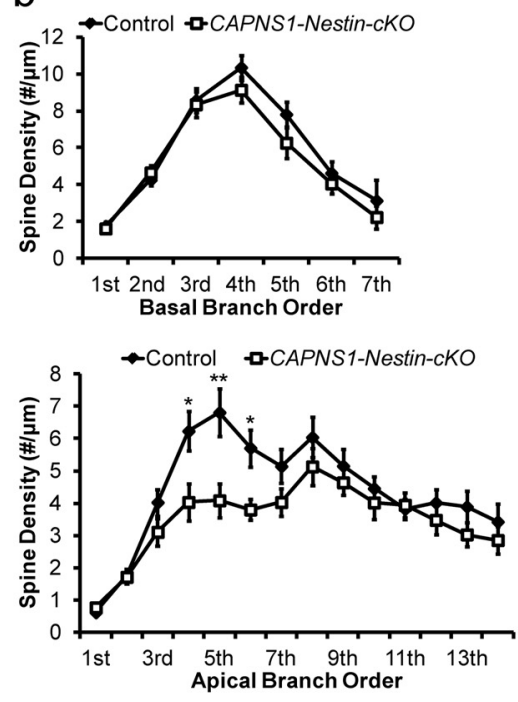

e
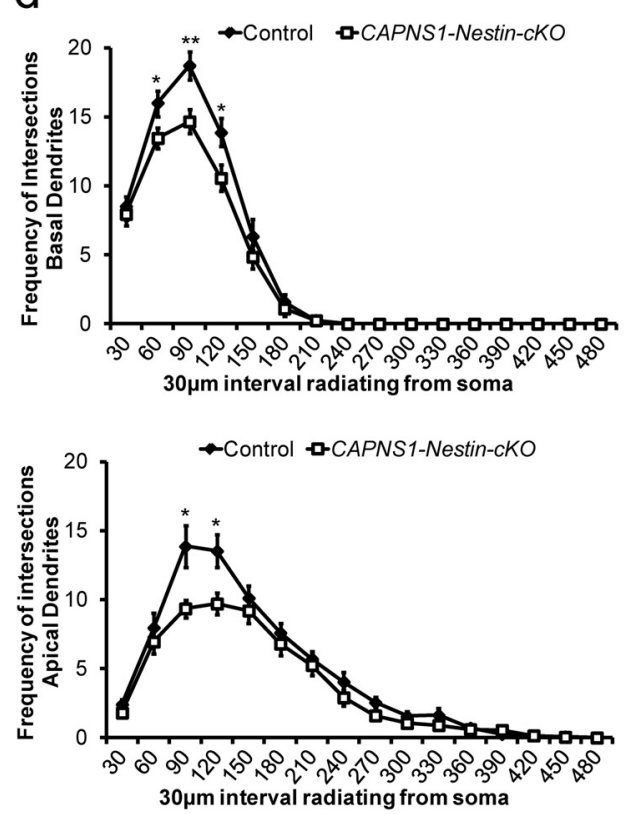
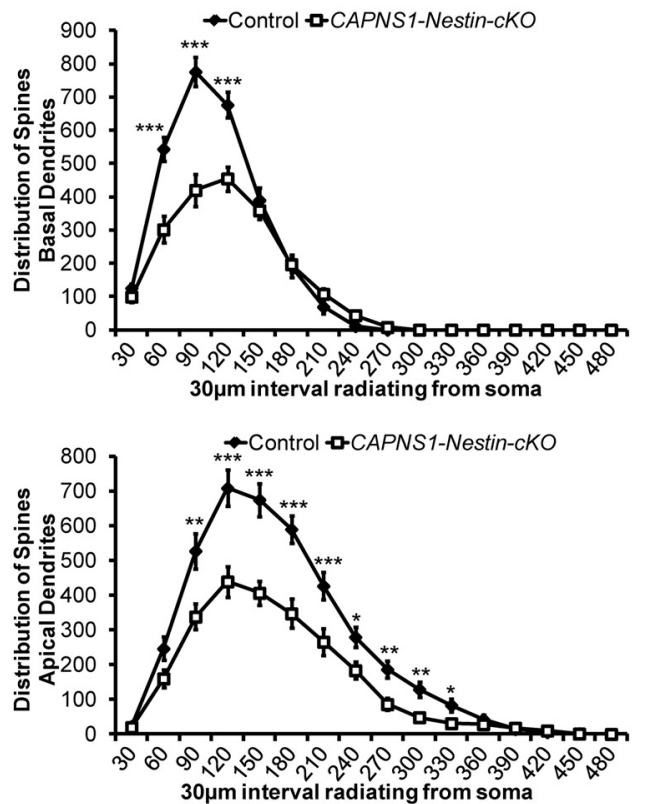
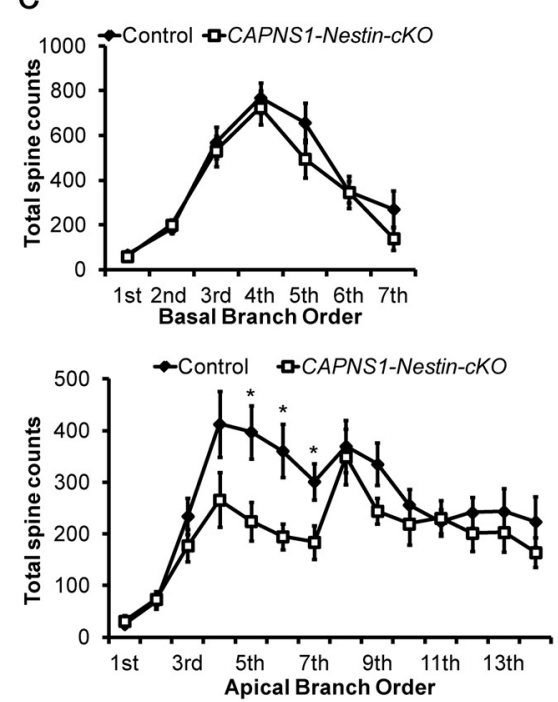

Figure 3. Altered morphology of hippocampal CA1 neuron dendrites in CAPNS1-Nestin-CKO mice. $a$, Representative segments of apical and basal dendrites of CA1 neurons in CAPNS1-Nestin-CKO and control littermates. Scale bar: $5 \mu \mathrm{m}$. Bottom, Representative photomicrograph of CA1 pyramidal neurons. Scale bar: $50 \mu \mathrm{m}$. $\boldsymbol{b}$, Representative graphs of spine density of basal and apical dendrites per branch orders. Spine density is expressed as the mean spine number per $1 \mu$ m dendritic segment. c, Representative graphs of total spine count of basal and apical dendrites per branch orders. $\boldsymbol{d}$, Scholl analysis of intersection pattern of basal and apical dendrites in CA1 neurons. $\boldsymbol{e}$, Distribution of spines in basal and apical dendrites at $30 \mu \mathrm{m}$ interval radiating distances from the soma in CA1 neurons. $f$, Representative graphs of basal and apical dendrites total length ( $n=27$ neurons for control littermates and $n=20$ neurons for CAPNS1-Nestin-cKOs). Data are mean \pm SEM. ${ }^{*} p<$ 0.05 (repeated ANOVA). ${ }^{* *} p<0.01$ (repeated ANOVA). ${ }^{* * *} p<0.001$ (repeated ANOVA).

shown). However, the input/output curve (stimulation intensity to evoked response) was significantly shifted downward in the mutant compared with controls (Fig. $5 a$ ). The decrease in fEPSPs was $\sim 30-40 \%$, broadly matching the decrease in the density of synapses observed in the mutant CA1 pyramidal neurons. We also determined the effects of $\theta$ burst stimulation (TBS) on fEPSPs (Fig. 5b). Interestingly, TBS-induced LTP was significantly reduced in hippocampal slices from CAPNS1-Nestin-cKO mice (fEPSP slope, compared with baseline, at $50 \mathrm{~min}$ after LTP induction: control $161 \pm 10 \%$; mutant $123 \pm 6 \%$; $p<0.001)$. Analysis of the burst responses during TBS revealed that, although the absolute levels of each burst responses were lower in the mutant than in the control, the overall increase observed during successive bursts exhibits a similar pattern in control and mutant mice (Fig. $5 c$ ).

The magnitude of LTP was also studied with whole-cell recording using a pairing protocol consisting of 3 brief high-frequency tetani ( 50 pulses at $100 \mathrm{~Hz}, 4$ s intervals) given at the end of a 3-minlong depolarization step at $0 \mathrm{mV}$. This protocol induced a $90.9 \pm$ $11.9 \%$ (control, $n=6 ; p<0.005$ ) increase in the amplitude of EPSC lasting for $>40 \mathrm{~min}$. This LTP was NMDA receptor-dependent because it was prevented by application of DL-2-amino-5phosphonovaleric acid (AP-5, $50 \mu \mathrm{M} ; 9.50 \pm 8.77 \%$ above baseline; $n=4 ; p>0.05$, data not shown). Interestingly, the same pairing protocol administered in slices from CAPNS1-Nestin-cKOs induced 


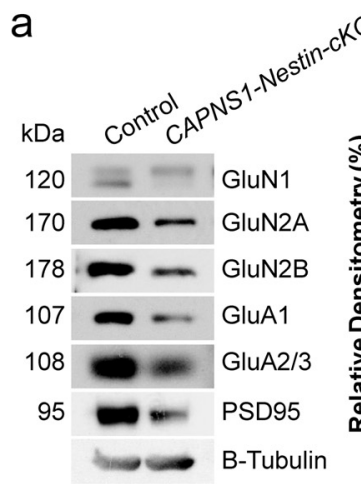

C NMDAR EPSCS
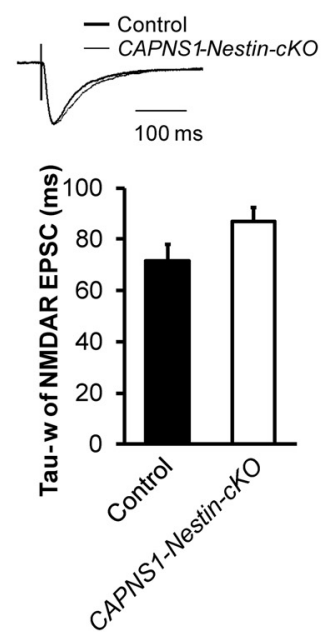

-Control aCAPNS1-Nestin-cKO

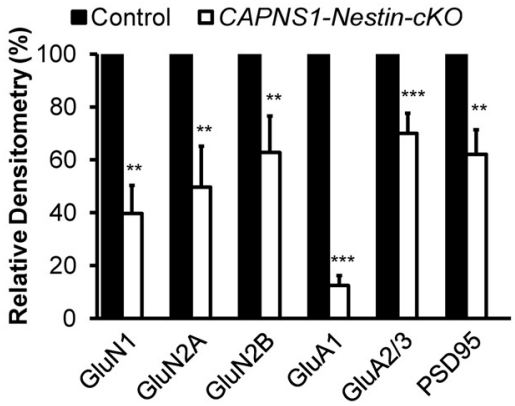

b

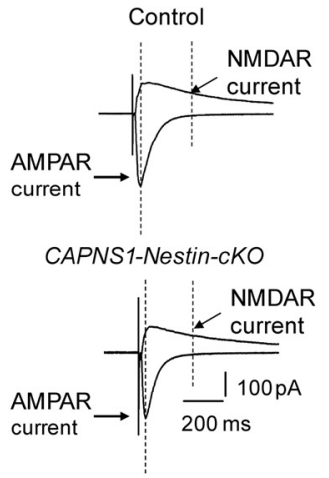

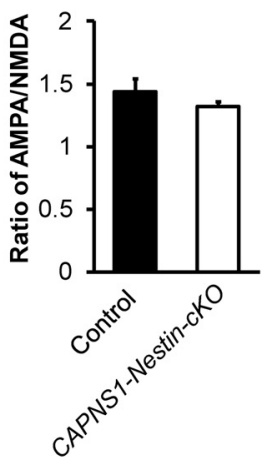

d
AMPAR EPSCS
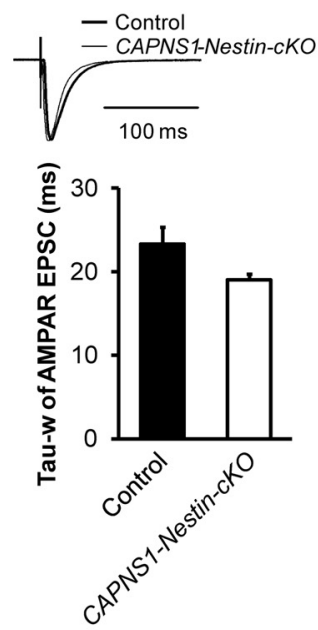

e

Control CAPNS1-Nestin-cKO
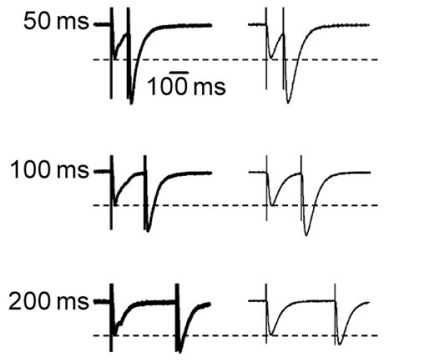

Control
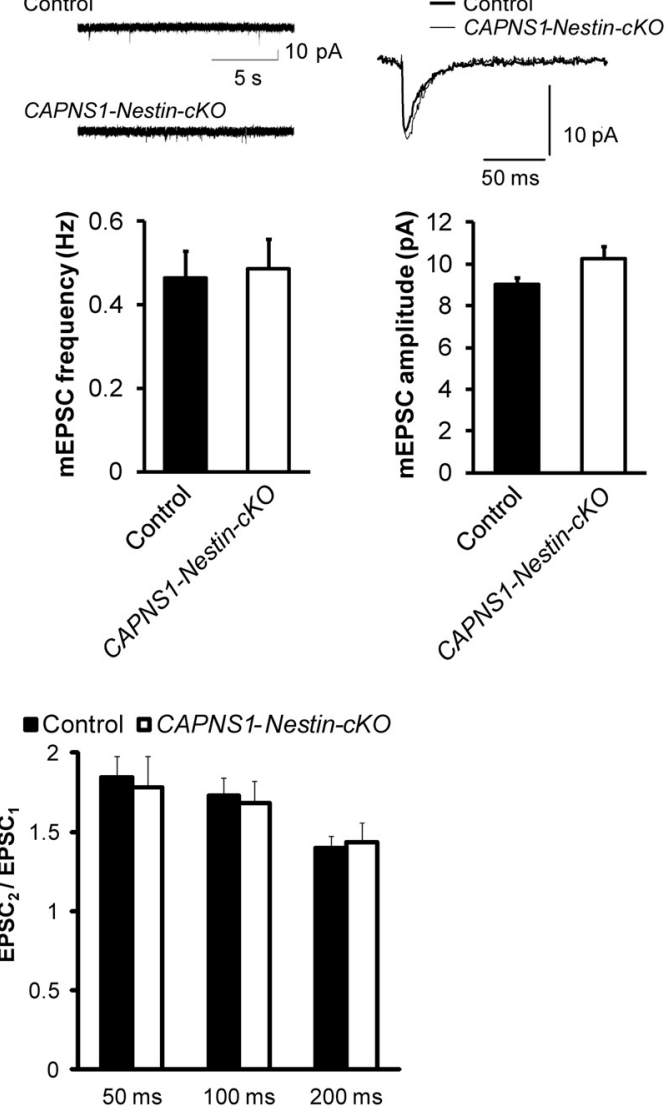

Figure 4. Hippocampal membrane protein distribution and glutamatergic synaptic transmission in hippocampal CA1 neurons of CAPNS1-Nestin-CKO and controls. $\boldsymbol{a}$, Representative immunoblots of membrane protein fractions of hippocampi from control and CAPNS1-Nestin-CKO probed with the indicated antibodies and densitometric quantification of changes in gray values expressed as mean \pm SEM. ${ }^{* *} p<0.01$ (Student's $t$ test). ${ }^{* * *} p<0.001$ (Student's $t$ test). Per genotype: $n=4$ for GluN1 and GluA1; $n=5$ for GluN2A, GluN2B, and PSD95; $n=3$ for GluA2/3. $\boldsymbol{b}$, Representing traces of AMPAR and NMDAR EPSCs at V-hold of -65 and $+40 \mathrm{mV}$, respectively (CAPNS1-Nestin-CKO 1.32 $\pm 0.04, n=9$ neurons from 3 mice; and controls $1.4 \pm 0.1, n=8$ neurons from 4 mice). At $-65 \mathrm{mV}$, the peak current is mainly contributed by AMPA receptors, whereas at $+40 \mathrm{mV}$ the peak current comes from both AMPA and NMDA receptors. c, Representative traces and weighted decay time constants of NMDAR and AMPAR EPSCs in CAPNS1-Nestin-CKO (NMDAR $87.07 \pm 5.46 \mathrm{~ms}, n=11$ neurons from 4 mice; and AMPAR $19.05 \pm 0.64 \mathrm{~ms}, n=9$ neurons from 4 mice) and controls (NMDAR71.55 $\pm 6.42 \mathrm{~ms}, n=6$ neurons from 4 mice and AMPAR $23.36 \pm 2.01 \mathrm{~ms}, n=9$ neurons from 4 mice). $\boldsymbol{d}$, Representative traces and averages of spontaneous AMPAR-mediated $\mathrm{mEPSC}$ recorded from neurons of CAPNS1-Nestin- $\mathrm{KO}$ (amplitude, $10.27 \pm 0.59 \mathrm{pA}$; frequency, $0.48 \pm 0.07 \mathrm{~Hz}, n=8$ neurons from 3 mice) and control mice (amplitude, $9.01 \pm 0.34 \mathrm{pA}$; frequency, $0.46 \pm 0.07 \mathrm{~Hz}, n=8$ neurons from 4 mice). $\boldsymbol{e}$, Representative traces and average of paired pulse ratios of EPSCs (AMPA + NMDAR) from neurons of CAPNS1-Nestin-cK0 mice (50 ms, $1.78 \pm 0.2$; $100 \mathrm{~ms}, 1.68 \pm 0.14 ; 200 \mathrm{~ms}, 1.44 \pm 0.12, n=9$ neurons from 3 mice) and controls ( $50 \mathrm{~ms}, 1.85 \pm 0.13 ; 100 \mathrm{~ms}, 1.73 \pm 0.11 ; 200 \mathrm{~ms}, 1.39 \pm 0.07, n=12$ neurons from 3 mice) .

only minimal LTP (control, $181 \pm 24 \%$; mutant, $132 \pm 29 \%$ at $30-40$ min after LTP induction; Fig. $5 d$ ).

\section{Impairments in spatial memory in calpain-deficient mice} We next determined whether the robust reduction in hippocampal LTP observed in CAPNS1-Nestin-cKO would be accompa- nied with deficits in hippocampal-dependent spatial memory. We thus tested CAPNS1-Nestin-cKO in the Morris Water Maze task. Significantly less CAPNS1-Nestin-cKO mice were able to reach the hidden platform on the last $3 \mathrm{~d}$ of training compared with littermate control mice, suggesting that CAPNS1-NestincKO have impaired spatial memory (Fig. 6a). This behavioral 
a

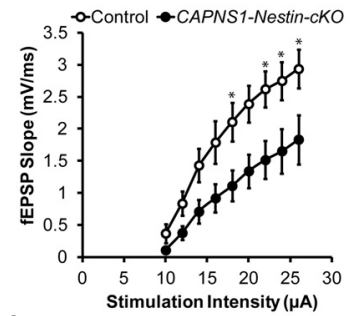

b

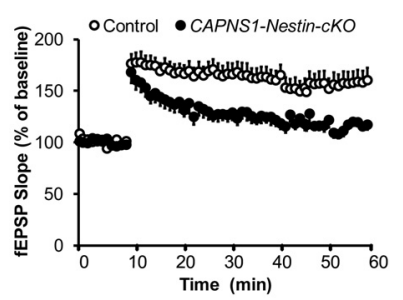

C

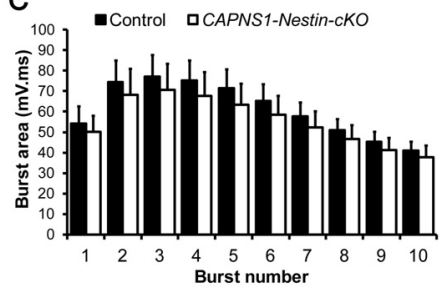

d

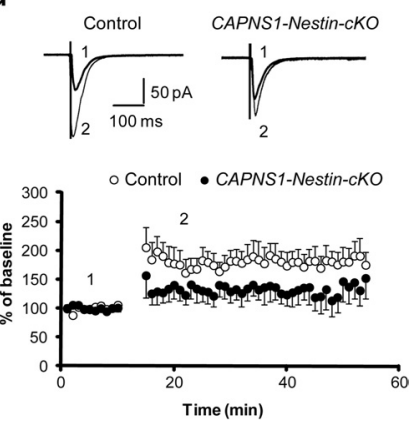

Figure 5. Features of synaptic transmission and plasticity in calpain-deficient mice assessed with field and patch-clamp recording. $\boldsymbol{a}$, Input/output curves. Amplitudes of the fEPSPs were determined for various intensities of stimulation. The curve is significantly shifted downward in the mutant mice. The results are mean $\pm \mathrm{SEM} ; n=5$ or 6 slices from 5 mice per genotype. ${ }^{*} p<$ 0.05 (Student's $t$ test). $\boldsymbol{b}$, TBS-induced LTP. TBS was delivered after $10 \mathrm{~min}$ of baseline recording and slopes of the fEPSPs monitored for an additional $50 \mathrm{~min}$. The values are normalized to the baseline and are mean \pm SEM; $n=5$ or 6 slices from 5 mice per genotype. ${ }^{* * *} p<0.001$ (Student's $t$ test). c, Areas of the burst responses during TBS ( 10 bursts of 4 pulses delivered at $100 \mathrm{~Hz}$, with an interburst interval of $200 \mathrm{~ms}$ ). Results are mean \pm SEM with no statistical differences between the two groups of mice; $n=5$ or 6 slices from 5 mice per genotype. $\boldsymbol{d}$, Patch-clamp recording of LTP. Representative traces of EPSC amplitudes $10 \mathrm{~min}$ before (1) and 50 min after (2) HFS pairing paradigm. Bottom, Time course of relative changes of EPSCS (for control $n=6$ neurons from 4 mice, for (APNS1-Nestin-CKO $n=5$ neurons form 4 mice). Data are mean \pm SEM. $p$ value is from the data comparison of $30-40 \mathrm{~min}$ EPSC average of mutants with those of control. ${ }^{* * *} p<0.001$ (Student's $t$ test).

deficit was not related to deficiencies in vision because there was no significant difference in the average time to find the visual platform (data now shown). In addition, examination of general motor activity by beam break and rotarod tests did not reveal any differences in the mutants (Fig. 6b,c). Finally, although the calpain-deficient mice showed less anxiety behavior in elevated plus maze test (Fig. $6 d$ ), the differences in the open field anxiety test were not observed (Fig. 6e). Collectively, these observations suggest that calpain is necessary for hippocampal LTP and learning and memory, and this may be related to a role in modulating the structure of neuronal dendrites and synapses.

\section{Calpain mediates neuronal cell death}

In contrast to their physiological roles in the CNS, classical calpains have previously been proposed to participate in neuronal cell death in several pathological conditions (Vosler et al., 2008). However, the direct role of calpain and its precise target in neurodegeneration need to be definitively demonstrated. Accordingly, we used this genetic model system to test the role of calpain in neuronal loss paradigms, including PD-related toxin exposure and ischemic stroke in vitro. $\mathrm{MPP}^{+}$, a metabolite of 1-methyl-4phenyl-1,2,3,6-tetrahydropyridine, is a mitochondrial complex 1 toxin, which promotes selective death of both dopaminergic neurons in vivo and several neuronal types in vitro, including cortical and midbrain cultures (Crocker et al., 2003; Smith et al., 2006; Qu et al., 2007; Huang et al., 2010). To test whether calpain plays a

a

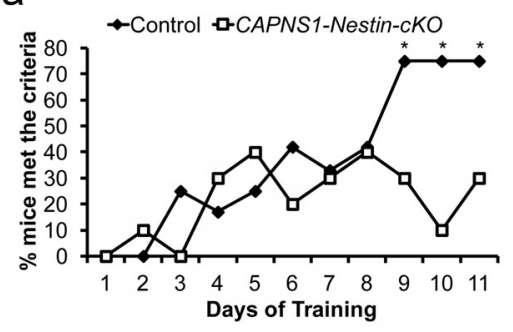

b

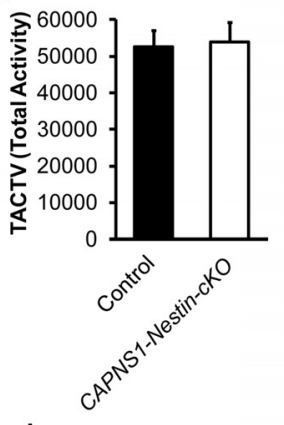

d

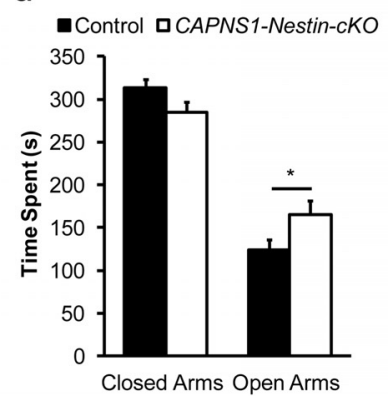

C

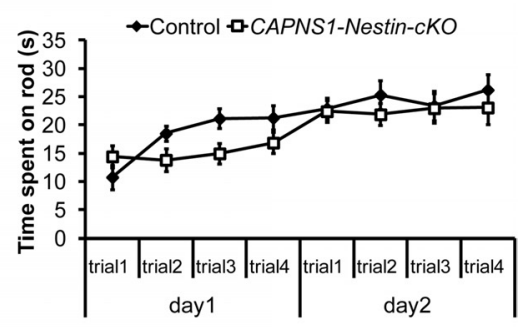

Figure 6. Spatial learning is deficient in CAPNS1-Nestin-CKO mice, whereas motor activity and anxiety behavior appear normal. $\boldsymbol{a}$, Percentage of CAPNS1-Nestin-cKO (males, $n=6$; females, $n=4$ ) and control littermate (males, $n=5$; females, $n=7$ ) mice successfully reaching the criteria of finding the platform in the Morris Water Maze, as described in Materials and Methods. $\boldsymbol{b}$, Locomotor activity assessed in a novel cage test. $\boldsymbol{c}$, Motor coordination examined by rotarod test. $\boldsymbol{d}, \boldsymbol{e}$, Anxiety observation performed with elevated plus maze (d) and open field test $(\boldsymbol{e})$. Data are mean \pm SEM. ${ }^{*} p<0.05$ (Student's $t$ test and repeated ANOVA). Controls: males, $n=10$; females, $n=11$; CAPNS1-Nestin-cKO: males, $n=11$; females, $n=10$.

role in neuronal death induced by this toxin, we first examined whether embryonic cortical cultures, derived from control or calpain-deficient animals, were differentially sensitive to $\mathrm{MPP}^{+}$. Neurons from CAPNS1-Nestin-cKO embryos were significantly less sensitive to the toxin (Fig. $7 a$ ). Because $\mathrm{TH}^{+}$neurons are grossly affected in PD, we also examined whether calpain may play a role in dopaminergic neuronal cell death as well. To do this, we crossed the floxed capns1 mice with a TH-Cre driver (Savitt et al., 2005) to specifically eliminate calpain-1/calpain-2 activity in $\mathrm{TH}^{+}$neurons. Neuronal cell cultures obtained from embryonic midbrains of CAPNS1-TH-cKO and control animals were treated with $\mathrm{MPP}^{+}$. Cell survival was assessed by evaluating the number of $\mathrm{TH}^{+}$neurons. Consistent with the result in cortical cultures generated from Nestin-Cre mice, neuronal survival after $\mathrm{MPP}^{+}$ treatment was significantly higher in calpain-deficient $\mathrm{TH}^{+}$neurons compared with controls (Fig. 7b).

To further evaluate the importance of calpain in neuronal injury, we also next tested models of ischemic cell death using in vitro glutamate- or hypoxia-induced excitotoxicity in cerebellar granule neurons (CGNs). Indeed, very early finding suggested 
a

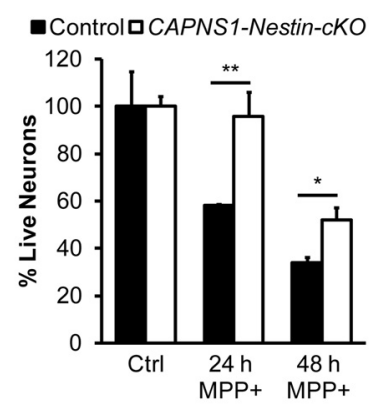

C

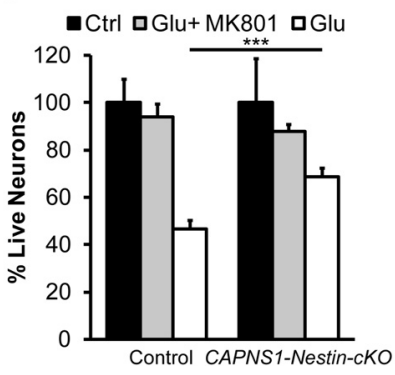

b

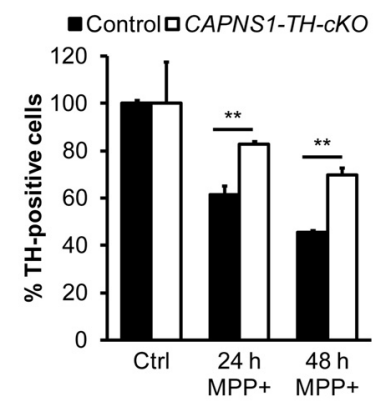

d

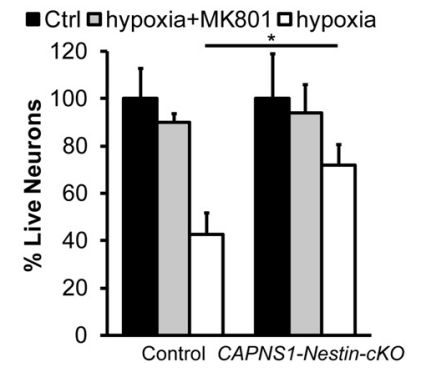

Figure 7. Calpain mediates excitotoxic neuronal death in PD- and ischemic-related in vitro models. $\boldsymbol{a}, \boldsymbol{b}, \mathrm{MPP}{ }^{+}$treatment of $(\boldsymbol{a})$ cortical neurons and $(\boldsymbol{b})$ midbrain neurons, respectively, at $20 \mu \mathrm{m}$ final concentration for 24 and $48 \mathrm{~h}$ revealed that calpain-deficient neurons were resistant to toxin-induced death (survival rate, $96 \pm 10 \%$ vs $58 \pm 1 \%$ at $24 \mathrm{~h} ; 52 \pm 5 \%$ vs $34 \pm 2 \%$ at $48 \mathrm{~h}$ and $83 \pm 1 \%$ vs $61 \pm 4 \%$ at $24 \mathrm{~h} ; 70 \pm 3 \%$ vs $45 \pm 1 \%$ at $48 \mathrm{~h}$, respectively; $n=4$ per genotype).c, Transient glutamate treatment of CGNs at $50 \mu \mathrm{m}$ final concentration for $70 \mathrm{~min}$ followed by $1.5 \mathrm{~h}$ reoxygenation in the presence and absence of $10 \mu \mathrm{M}$ MK801 (survival rate, $68 \pm 4 \%$ vs $47 \pm 4 \% ; n=6$ per genotype). $\boldsymbol{d}$, Hypoxia ( $1 \%$ oxygen) treatment of CGNs for $4-5 \mathrm{~h}$ followed by $1-2 \mathrm{~h}$ reoxygenation in the presence and absence of $10 \mu \mathrm{m}$ MK801 (survival rate, $72 \pm 9 \%$ vs $43 \pm 9 \% ; n=4$ per genotype). Data are mean \pm SEM. ${ }^{*} p<0.05$ (Student's $t$ test). ${ }^{* *} p<0.01$ (Student's $t$ test). ${ }^{* * *} p<0.001$ (Student's $t$ test).

that in vitro translational suppression of calpain-1 reduced excitotoxic damage resulting from NMDA receptor activation (Bednarski et al., 1995). Here, CGNs derived from postnatal cerebellum of CAPNS1-Nestin-cKO and controls were transiently subjected to glutamate in the presence or absence of MK801, an NMDA receptor blocker, and neuronal survival was assessed by nuclear integrity. Calpain-deficient neurons were less sensitive to glutamate than control littermates (Fig. 7c). Similarly, CGNs obtained from the mutants were significantly protected against hypoxia-induced cell death (Fig. $7 d$ ). Together, these results suggest a direct role of calpain in multiple mechanisms of neuronal cell death.

\section{Calpain-mediated cleavage of $\mathrm{p} 35$, the Cdk5 regulatory subunit, plays a critical role in neuronal damage}

The generation of calpain-deficient neurons afforded the opportunity to ascertain the importance of selected substrates of calpain in neuronal death. Previous studies, including from our laboratory, suggested that calpain-mediated cleavage of p35, a cyclin-dependent kinase 5 (Cdk5) regulatory subunit, to p25 elicits inappropriate activation of $\mathrm{Cdk} 5$, which drives neuronal cell death (Lee et al., 2000; Smith et al., 2006). However, it is not completely clear whether p35 cleavage to p25 is mediated exclusively by calpain, or how critical this cleavage is to the neuronal cell death process (O'Hare et al., 2005). To explore this question, cortical cultures from CAPNS1-Nestin-cKO and control animals were exposed to $\mathrm{MPP}^{+}$for 24 or $48 \mathrm{~h}$. Expression of p35 and p25
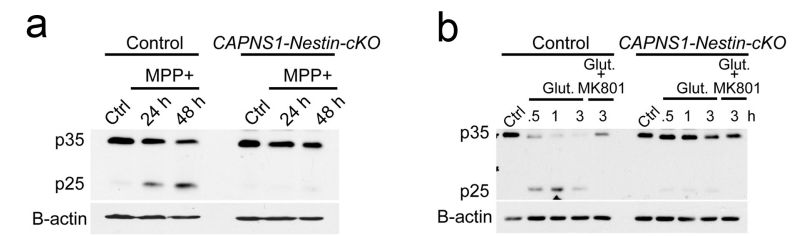

C

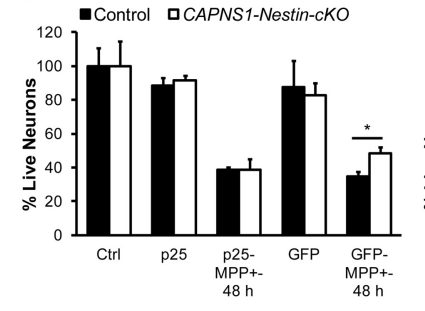

d

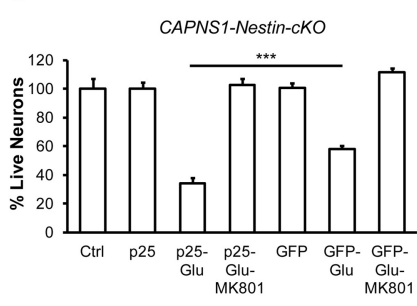

Figure 8. p35 is a target of calpain, and the p25 cleavage product mediates excitotoxic neuronal death. $\boldsymbol{a}, \boldsymbol{b}$, Representative immunoblots showing the increase in $\mathrm{p} 35$ cleavage to p25 after $(\boldsymbol{a}) \mathrm{MPP}^{+}$and $(\boldsymbol{b})$ glutamate treatment in cortical neurons and (GNs, respectively, from control mice but not CAPNS1-Nestin-CKO ( $n=5$ per genotype). $\boldsymbol{c}, \boldsymbol{d}$, Graphical representation of sensitization of ( $\boldsymbol{c}$ ) cortical neurons and ( $\boldsymbol{d}$ ) CGNs to MPP ${ }^{+}$and glutamate, respectively, and the resensitization of calpain-deficient neurons by AAV-directed p25 overexpression ( $n=3$ per genotype). Data are mean \pm SEM of the number of intact nuclei. $c,{ }^{*} p<0.05$, controls versus mutant neurons expressing GFP and treated with MPP ${ }^{+}$(Student's $t$ test). $\boldsymbol{d},{ }^{* * *} p<0.001$, neurons from mutants expressing either p25 or GFP and treated with glutamate (Student's $t$ test).

was assessed by immunoblot analysis of cell lysates using a C-terminal polyclonal antibody that recognizes both the fulllength $\mathrm{p} 35$ and the $\mathrm{p} 25$ cleaved product. We observed a dramatic increase in p25 expression associated with a reduction in p35 protein levels after $\mathrm{MPP}^{+}$or glutamate treatment in controls (Fig. $8 a, b$ ). Importantly, we could not detect p25 formation or loss of $\mathrm{p} 35$ in calpain-deficient neurons after $\mathrm{MPP}^{+}$or glutamate treatment (Fig. 8a,b). These observations demonstrate an essential role of calpain in cleavage of p35 to p25 in injured neurons. To functionally test the involvement of calpain-induced p 25 formation in cell death, AAV was used to rescue p25 expression and to determine whether the protection associated with calpain deficiency could be reversed. As predicted, cortical cultures from CAPNS1-Nestin-cKO infected with a control GFP-expressing AAV displayed less neuronal death than wild-type cells upon $\mathrm{MPP}^{+}$challenge. In contrast, infection with p25 expressing AAV restored $\mathrm{MPP}^{+}$-induced cell death in calpain-deficient cells to the same levels seen in control cells (Fig. 8c). Glutamate-induced cell death was also restored in calpain-deficient neurons by rescuing p25 expression (Fig. $8 d$ ). Interestingly, consistent with what has been shown previously (Fischer et al., 2005), short-term overexpression of p25 did not initiate neuronal death by itself. Together, these results provide compelling evidence for the critical role of calpain-mediated conversion of p35 to p25 in two different models of neuronal cell death.

\section{Discussion}

Although it has been four decades since the discovery of the ubiquitous calpains, its biological roles remain elusive. Animal models to identify the function of these proteases in the CNS have been limited because of early embryonic lethality or lack of phenotype in germline knock-out mice. CAPN2 knock-out mice (lacking calpain-2) died before the implantation stage of development and germline deletion of CAPNS1 (disrupting both calpain-1 and calpain-2) caused embryonic lethality because of cardiovascular defects (Arthur et al., 2000; Dutt et al., 2006). 
Although CAPN1 knock-out mice (lacking calpain-1) survived to adulthood, they did not display brain phenotypes, such as alterations in synaptic plasticity (Grammer et al., 2005). In the present studies, we describe a unique conditional deletion model of both calpain-1 and calpain-2 to assess the roles of these proteases in brain development/function and pathology.

Studies using pharmacological calpain inhibitors have supported a role for calpain in several biological processes critical for CNS development. Our own experience (Sedarous et al., 2003) as well as that of others (Luo and O'Leary, 2005; Touma et al., 2007) has shown that pharmacological calpain inhibitors can cause dramatic and rapid axon retraction in vitro, implicating calpain in the biochemistry of axon maturation and maintenance (Qin et al., 2010). In addition, calpain has been implicated in developmental neuronal death, a process critical for sculpting the mature brain (Gil-Parrado et al., 2002; Li et al., 2009). Given these observations, it was surprising that mice with CNS calpain deficiency are viable and born with normal general morphology and unaltered developmental apoptosis and proliferation in the brain. Considering that nestin expression begins at E.7.5 (Berube et al., 2005), a time when the earliest processes of CNS development occurs (Theiler, 1989), our findings strongly suggest that, although calpain may play crucial roles in development of other organ systems, it appears dispensable for basic CNS establishment.

Although gross brain development and architecture was normal, calpain deficiency resulted in a decline in spine density and deterioration of branch ramifications/bifurcations in basal and apical dendrites in hippocampal CA1 pyramidal neurons. A caveat to these observations is that we cannot rule out the possibility that loss of staining rather than loss of spine structures is occurring. However, these staining differences would have to occur specifically in spines because soma and dendritic structures are clearly present. Our results are also supported by previous work suggesting that calpain mediates changes in cytoskeletal structure and organization (Wilson et al., 2000; Fischer et al., 2005) by cleaving potential substrates, including spectrin and MAP2 (Fischer et al., 1991; Zadran et al., 2010a).

These changes in neuronal structural complexity led us to examine whether this was associated with altered synaptic transmission. Indeed, calpain has also been suggested to cleave a number of substrates relevant to excitatory transmission (Doshi and Lynch, 2009). Our results show that brain-specific calpain deficiency leads to reduced levels of some glutamate receptor components and PSDs. These findings suggest that calpain does not directly cleave these substrates but may actually regulate their levels of expression. This is possibly through effects of calpain on signaling pathways regulating gene expression. Calpain is implicated in the cleavage of several transcription factors, such as c-Jun and c-Fos (Goll et al., 2003), MEF2 (Smith et al., 2006), and NFкB (Sedarous et al., 2003). These transcriptional factors are proposed to regulate expression of NMDA receptor subunits (Bai and Hoffman, 2009). Intriguingly, the ultrastructural and synaptic protein deficits observed in the CAPNS1-Nestin-cKOs did not translate into obvious defects at individual glutamatergic CA1 synapses, as the amplitude of mEPSCs was unaltered. This may reflect the general robust compensatory ability of synapses to maintain faithful transmission despite deletion of key synaptic components, for instance, GluA1 (Zamanillo et al., 1999), TARP $\gamma$-8 (Rouach et al., 2005), GluA2 (Toyoda et al., 2009), and others. The overall decrease in input/output responses observed in CA1 region of CAPNS1-Nestin-cKOs may reflect the overall decrease in spine density observed.
Calpain-deleted mice displayed a significant reduction in LTP, supporting a central role for calpain in synapse plasticity. This is also consistent with our results showing reduced memory as evaluated in the Morris Water Maze Test. The observed reduction in LTP with calpain loss is consistent with a number of previous observations. First, pharmacological as well as antisense-based inhibitors of calpains blocked LTP (del Cerro et al., 1990; Denny et al., 1990; Vanderklish et al., 1996). Furthermore, calpains are localized in spines and can be activated by threshold levels of inducing stimulation (Baudry and Lynch, 2001; Zadran et al., 2010b). However, and in contrast to these findings, calpain-1 knock-out mice did not display impaired LTP (Grammer et al., 2005). Whether this discrepancy is the result of differences in the LTP paradigm used is unclear at present. Here, we provide compelling genetic evidence that calpain is required for LTP. Considering the absence of an LTP phenotype in calpain-1 knock-out mice (Grammer et al., 2005), our observations suggest that either calpain-2 deficiency is responsible for this phenotype in CAPNS1-Nestin-cKO mice or that there is functional redundancy between calpain-1/calpain-2 isoforms with respect to this function. The former interpretation is also consistent with recent reports indicating that calpain-2 can be activated by $\mathrm{Ca}^{+2}$-independent systems (Zadran et al., 2010b), giving a possible explanation for calpain-2 activation with physiological intracellular calcium concentration; and that calpain-2 downregulation using a novel rabies-virus glycoprotein-chimeric peptide to deliver calpain-2 siRNA to the brain resulted in impairments in LTP and learning and memory (Zadran et al., 2012). Finally, it is important to emphasize that we cannot presently distinguish between subtle developmental defects, which may affect LTP/behavior in these calpain-deficient mice versus more specific effects of calpain deficiency on signaling processes in the adult brain.

In addition to defining a role of calpain in brain function under normal conditions, our results interestingly indicate that it can participate in neuropathological processes under stress situations. Calpain activation has been associated with a number of death paradigms, both in vitro and in vivo, including those linked to stroke and PD (Crocker et al., 2003; Ray and Banik, 2003; Bevers and Neumar, 2008). Relevant to the former, both in vitro and in vivo experiments have shown that proteolysis of calpainspecific substrates is elevated in the hippocampal and neocortical areas in focal and global ischemia (Hong et al., 1994; Bartus et al., 1995; Bednarski et al., 1995). In addition, several studies have provided evidence that pretreatment or post-treatment with calpain inhibitors has neuroprotective action in in vitro and in vivo ischemic models (Vosler et al., 2008; Peng et al., 2011). In terms of PD, we have shown that calpain-1 and calpain-2 are activated in both in vitro and in vivo models of neuronal loss induced by the dopaminergic toxin 1-methyl-4-phenyl-1,2,3,6-tetrahydropyridine/MPP ${ }^{+}$(Crocker et al., 2003; Qu et al., 2007; Huang et al., 2010). Calpain inhibitors also protected dopaminergic neurons from death in these paradigms. Our present genetic work provides further support for the critical nature of calpains in neuronal injury. We find that calpain deficiency promotes survival under multiple contexts of hypoxia, excitotoxicity, and mitochondrial dysfunction. In addition, calpain involvement in death induced by injury contrasts with developmental death examined in the embryo. What is the mechanism by which calpain promotes injury-mediated death? We and others have previously proposed that calpain cleaves the C $\mathrm{dk} 5$ activator $\mathrm{p} 35$ to a more stable active p25 form (Lee et al., 2000; O'Hare et al., 2005; Smith et al., 2006). In the contexts of stroke and PD, we have shown that 
this is associated with increased Cdk5 activation (Smith et al., 2006). Our calpain deficiency model allowed us to more concretely examine whether calpain was indeed critical to p25 formation and whether this formation is central to the death process. In multiple paradigms of neuronal death, we show that calpain-deficient neurons have significantly impaired p 25 formation compared with controls. Conversely, the protection afforded by calpain deficiency can be reversed by ectopic expression of p25. This supports a central role for calpain-mediated p25 formation in the paradigms of neuronal death presently examined. Given that p25 is also reported to be involved in synaptic plasticity (Fischer et al., 2005), it is intriguing to speculate that cleavage of p35 to p25 might be one of the central events that connects calpain to some of its physiological and pathophysiological functions. Finally, it is important to note that whether or not genetic calpain deficiency plays a role in adult degeneration/injury has not been presently studied.

In conclusion, our analysis of a conditional model of calpain deficiency in the CNS has provided a clearer understanding of calpain biology in the brain regarding CNS development, synaptic plasticity, and specific neuronal death paradigms. We think that this conditional model will continue to generate critical information on calpain function in the brain and in disease.

\section{References}

Arthur JS, Elce JS, Hegadorn C, Williams K, Greer PA (2000) Disruption of the murine calpain small subunit gene, Capn4: calpain is essential for embryonic development but not for cell growth and division. Mol Cell Biol 20:4474-4481. CrossRef Medline

Bai G, Hoffman PW (2009) Transcriptional regulation of NMDA receptor expression (Van Dongen AM, ed). Boca Raton, FL: CRC. Medline

Bartus RT, Dean RL, Cavanaugh K, Eveleth D, Carriero DL, Lynch G (1995) Time-related neuronal changes following middle cerebral artery occlusion: implications for therapeutic intervention and the role of calpain. J Cereb Blood Flow Metab 15:969-979. CrossRef Medline

Baudry M, Lynch G (2001) Remembrance of arguments past: how well is the glutamate receptor hypothesis of LTP holding up after 20 years? Neurobiol Learn Mem 76:284-297. CrossRef Medline

Bednarski E, Vanderklish P, Gall C, Saido TC, Bahr BA, Lynch G (1995) Translational suppression of calpain I reduces NMDA-induced spectrin proteolysis and pathophysiology in cultured hippocampal slices. Brain Res 694:147-157. CrossRef Medline

Bérubé NG, Mangelsdorf M, Jagla M, Vanderluit J, Garrick D, Gibbons RJ, Higgs DR, Slack RS, Picketts DJ (2005) The chromatin-remodeling protein ATRX is critical for neuronal survival during corticogenesis. J Clin Invest 115:258-267. CrossRef Medline

Bevers MB, Neumar RW (2008) Mechanistic role of calpains in postischemic neurodegeneration. J Cereb Blood Flow Metab 28:655-673. CrossRef Medline

Chen HX, Otmakhov N, Lisman J (1999) Requirements for LTP induction by pairing in hippocampal CA1 pyramidal cells. J Neurophysiol 82:526532. Medline

Chung TC, Liang YC, Yeh JY, Ou BR (2004) Stabilization of calpain large subunits by overexpression of truncated calpain small subunit in L8 myoblasts. Tissue Cell 36:181-187. CrossRef Medline

Crocker SJ, Smith PD, Jackson-Lewis V, Lamba WR, Hayley SP, Grimm E, Callaghan SM, Slack RS, Melloni E, Przedborski S, Robertson GS, Anisman H, Merali Z, Park DS (2003) Inhibition of calpains prevents neuronal and behavioral deficits in an MPTP mouse model of Parkinson's disease. J Neurosci 23:4081-4091. Medline

del Cerro S, Larson J, Oliver MW, Lynch G (1990) Development of hippocampal long-term potentiation is reduced by recently introduced calpain inhibitors. Brain Res 530:91-95. CrossRef Medline

Denny JB, Polan-Curtain J, Ghuman A, Wayner MJ, Armstrong DL (1990) Calpain inhibitors block long-term potentiation. Brain Res 534:317-320. CrossRef Medline

Doshi S, Lynch DR (2009) Calpain and the glutamatergic synapse. Front Biosci (Schol Ed) 1:466-476. CrossRef Medline

Dutt P, Croall DE, Arthur JS, Veyra TD, Williams K, Elce JS, Greer PA (2006)
$\mathrm{m}$-Calpain is required for preimplantation embryonic development in mice. BMC Dev Biol 6:3. CrossRef Medline

Fischer A, Sananbenesi F, Pang PT, Lu B, Tsai LH (2005) Opposing roles of transient and prolonged expression of p25 in synaptic plasticity and hippocampus-dependent memory. Neuron 48:825-838. CrossRef Medline

Fischer I, Romano-Clarke G, Grynspan F (1991) Calpain-mediated proteolysis of microtubule associated proteins MAP1B and MAP2 in developing brain. Neurochem Res 16:891-898. CrossRef Medline

Gil-Parrado S, Fernández-Montalvan A, Assfalg-Machleidt I, Popp O, Bestvater F, Holloschi A, Knoch TA, Auerswald EA, Welsh K, Reed JC, Fritz H, Fuentes-Prior P, Spiess E, Salvesen GS, Machleidt W (2002) Ionomycinactivated calpain triggers apoptosis: a probable role for $\mathrm{Bcl}-2$ family members. J Biol Chem 277:27217-27226. CrossRef Medline

Goll DE, Thompson VF, Li H, Wei W, Cong J (2003) The calpain system. Physiol Rev 83:731-801. CrossRef Medline

Grammer M, Kuchay S, Chishti A, Baudry M (2005) Lack of phenotype for LTP and fear conditioning learning in calpain 1 knock-out mice. Neurobiol Learn Mem 84:222-227. CrossRef Medline

Honda S, Marumoto T, Hirota T, Nitta M, Arima Y, Ogawa M, Saya H (2004) Activation of m-calpain is required for chromosome alignment on the metaphase plate during mitosis. J Biol Chem 279:10615-10623. CrossRef Medline

Hong SC, Goto Y, Lanzino G, Soleau S, Kassell NF, Lee KS (1994) Neuroprotection with a calpain inhibitor in a model of focal cerebral ischemia. Stroke 25:663-669. CrossRef Medline

Huang E, Qu D, Zhang Y, Venderova K, Haque ME, Rousseaux MW, Slack RS, Woulfe JM, Park DS (2010) The role of Cdk5-mediated apurinic/ apyrimidinic endonuclease 1 phosphorylation in neuronal death. Nat Cell Biol 12:563-571. CrossRef Medline

Imamura Y, Ma CL, Pabba M, Bergeron R (2008) Sustained saturating level of glycine induces changes in NR2B-containing-NMDA receptor localization in the CA1 region of the hippocampus. J Neurochem 105:24542465. CrossRef Medline

Kim RH, Smith PD, Aleyasin H, Hayley S, Mount MP, Pownall S, Wakeham A, You-Ten AJ, Kalia SK, Horne P, Westaway D, Lozano AM, Anisman H, Park DS, Mak TW (2005) Hypersensitivity of DJ-1-deficient mice to 1-methyl-4-phenyl-1,2,3,6-tetrahydropyrindine (MPTP) and oxidative stress. Proc Natl Acad Sci U S A 102:5215-5220. CrossRef Medline

König N, Raynaud F, Feane H, Durand M, Mestre-Francès N, Rossel M, Ouali A, Benyamin Y (2003) Calpain 3 is expressed in astrocytes of rat and Microcebus brain. J Chem Neuroanat 25:129-136. CrossRef Medline

Lee MS, Kwon YT, Li M, Peng J, Friedlander RM, Tsai LH (2000) Neurotoxicity induces cleavage of p35 to p25 by calpain. Nature 405:360-364. CrossRef Medline

Li Y, Bondada V, Joshi A, Geddes JW (2009) Calpain 1 and Calpastatin expression is developmentally regulated in rat brain. Exp Neurol 220: 316-319. CrossRef Medline

Luo L, O'Leary DD (2005) Axon retraction and degeneration in development and disease. Annu Rev Neurosci 28:127-156. CrossRef Medline

Lynch G, Baudry M (1984) The biochemistry of memory: a new and specific hypothesis. Science 224:1057-1063. CrossRef Medline

Martina M, Gorfinkel Y, Halman S, Lowe JA, Periyalwar P, Schmidt CJ, Bergeron R (2004) Glycine transporter type 1 blockade changes NMDA receptor-mediated responses and LTP in hippocampal CA1 pyramidal cells by altering extracellular glycine levels. J Physiol 557:489-500. CrossRef Medline

Martinez JA, Zhang Z, Svetlov SI, Hayes RL, Wang KK, Larner SF (2010) Calpain and caspase processing of caspase-12 contribute to the ER stressinduced cell death pathway in differentiated PC12 cells. Apoptosis 15: 1480-1493. CrossRef Medline

Mouatt-Prigent A, Karlsson JO, Agid Y, Hirsch EC (1996) Increased M-calpain expression in the mesencephalon of patients with Parkinson's disease but not in other neurodegenerative disorders involving the mesencephalon: a role in nerve cell death? Neuroscience 73:979-987. CrossRef Medline

O'Hare MJ, Kushwaha N, Zhang Y, Aleyasin H, Callaghan SM, Slack RS, Albert PR, Vincent I, Park DS (2005) Differential roles of nuclear and cytoplasmic cyclin-dependent kinase 5 in apoptotic and excitotoxic neuronal death. J Neurosci 25:8954-8966. CrossRef Medline

Peng S, Kuang Z, Zhang Y, Xu H, Cheng Q (2011) The protective effects and potential mechanism of Calpain inhibitor Calpeptin against focal cerebral 
ischemia-reperfusion injury in rats. Mol Biol Rep 38:905-912. CrossRef Medline

Qin Q, Liao G, Baudry M, Bi X (2010) Role of calpain-mediated p53 truncation in semaphorin 3A-induced axonal growth regulation. Proc Natl Acad Sci U S A 107:13883-13887. CrossRef Medline

Qu D, Rashidian J, Mount MP, Aleyasin H, Parsanejad M, Lira A, Haque E, Zhang Y, Callaghan S, Daigle M, Rousseaux MW, Slack RS, Albert PR, Vincent I, Woulfe JM, Park DS (2007) Role of Cdk5-mediated phosphorylation of Prx2 in MPTP toxicity and Parkinson's disease. Neuron 55:37-52. CrossRef Medline

Rashidian J, Iyirhiaro G, Aleyasin H, Rios M, Vincent I, Callaghan S, Bland RJ, Slack RS, During MJ, Park DS (2005) Multiple cyclin-dependent kinases signals are critical mediators of ischemia/hypoxic neuronal death in vitro and in vivo. Proc Natl Acad Sci U S A 102:14080-14085. CrossRef Medline

Ray SK, Banik NL (2003) Calpain and its involvement in the pathophysiology of CNS injuries and diseases: therapeutic potential of calpain inhibitors for prevention of neurodegeneration. Curr Drug Targets CNS Neurol Disord 2:173-189. CrossRef Medline

Rouach N, Byrd K, Petralia RS, Elias GM, Adesnik H, Tomita S, Karimzadegan S, Kealey C, Bredt DS, Nicoll RA (2005) TARP $\gamma-8$ controls hippocampal AMPA receptor number, distribution and synaptic plasticity. Nat Neurosci 8:1525-1533. CrossRef Medline

Sato K, Kawashima S (2001) Calpain function in the modulation of signal transduction molecules. Biol Chem 382:743-751. CrossRef Medline

Savitt JM, Jang SS, Mu W, Dawson VL, Dawson TM (2005) Bcl-x is required for proper development of the mouse substantia nigra. J Neurosci 25: 6721-6728. CrossRef Medline

Sedarous M, Keramaris E, O'Hare M, Melloni E, Slack RS, Elce JS, Greer PA, Park DS (2003) Calpains mediate p53 activation and neuronal death evoked by DNA damage. J Biol Chem 278:26031-26038. CrossRef Medline

Smith PD, Mount MP, Shree R, Callaghan S, Slack RS, Anisman H, Vincent I, Wang X, Mao Z, Park DS (2006) Calpain-regulated p35/cdk5 plays a central role in dopaminergic neuron death through modulation of the transcription factor myocyte enhancer factor 2. J Neurosci 26:440-447. CrossRef Medline

Sorimachi H, Hata S, Ono Y (2011) Impact of genetic insights into calpain biology. J Biochem 150:23-37. CrossRef Medline

Tan Y, Dourdin N, Wu C, De Veyra T, Elce JS, Greer PA (2006) Conditional disruption of ubiquitous calpains in the mouse. Genesis 44:297-303. CrossRef Medline
Theiler K (1989) The house mouse. Zurich: Springer.

Touma E, Kato S, Fukui K, Koike T (2007) Calpain-mediated cleavage of collapsin response mediator protein (CRMP)-2 during neurite degeneration in mice. Eur J Neurosci 26:3368-3381. CrossRef Medline

Toyoda H, Zhao MG, Ulzhöfer B, Wu LJ, Xu H, Seeburg PH, Sprengel R, Kuner R, Zhuo M (2009) Roles of the AMPA receptor subunit GluA1 but not GluA2 in synaptic potentiation and activation of ERK in the anterior cingulate cortex. Mol Pain 5:46. CrossRef Medline

Vanderklish P, Bednarski E, Lynch G (1996) Translational suppression of calpain blocks long-term potentiation. Learn Mem 3:209-217. CrossRef Medline

Vanderluit JL, Wylie CA, McClellan KA, Ghanem N, Fortin A, Callaghan S, MacLaurin JG, Park DS, Slack RS (2007) The retinoblastoma family member p107 regulates the rate of progenitor commitment to a neuronal fate. J Cell Biol 178:129-139. CrossRef Medline

Vosler PS, Brennan CS, Chen J (2008) Calpain-mediated signaling mechanisms in neuronal injury and neurodegeneration. Mol Neurobiol 38:78100. CrossRef Medline

Wilson MT, Kisaalita WS, Keith CH (2000) Glutamate-induced changes in the pattern of hippocampal dendrite outgrowth: a role for calciumdependent pathways and the microtubule cytoskeleton. J Neurobiol 43: 159-172. CrossRef Medline

Zadran S, Bi X, Baudry M (2010a) Regulation of calpain-2 in neurons: implications for synaptic plasticity. Mol Neurobiol 42:143-150. CrossRef Medline

Zadran S, Jourdi H, Rostamiani K, Qin Q, Bi X, Baudry M (2010b) Brainderived neurotrophic factor and epidermal growth factor activate neuronal $\mathrm{m}$-calpain via mitogen-activated protein kinase-dependent phosphorylation. J Neurosci 30:1086-1095. CrossRef Medline

Zadran S, Akopian G, Zadran H, Walsh J, Baudry M (2012) RVG-mediated calpain 2 gene silencing in the brain impairs learning and memory. Neuromolecular Med. Advance online publication. Retrieved August 19, 2012. doi:10.1007/s12017-012-8196-8. CrossRef Medline

Zamanillo D, Sprengel R, Hvalby O, Jensen V, Burnashev N, Rozov A, Kaiser KM, Köster HJ, Borchardt T, Worley P, Lübke J, Frotscher M, Kelly PH, Sommer B, Andersen P, Seeburg PH, Sakmann B (1999) Importance of AMPA receptors for hippocampal synaptic plasticity but not for spatial learning. Science 284:1805-1811. CrossRef Medline

Zhang Z, Larner SF, Liu MC, Zheng W, Hayes RL, Wang KK (2009) Multiple alphaII-spectrin breakdown products distinguish calpain and caspase dominated necrotic and apoptotic cell death pathways. Apoptosis 14: 1289-1298. CrossRef Medline 